\title{
Carbon oxidation and bioirrigation in sediments along a Skagerrak-Kattegat-Belt Sea depth transect
}

\author{
Erik Kristensen ${ }^{1, *}$, Hans Røy ${ }^{2}$, Kristian Debrabant ${ }^{3}$, Thomas Valdemarsen ${ }^{1}$ \\ ${ }^{1}$ Department of Biology, University of Southern Denmark, 5230 Odense M, Denmark \\ ${ }^{2}$ Center for Geomicrobiology, Department of Bioscience, Aarhus University, 8000 Aarhus C, Denmark \\ ${ }^{3}$ Applied Mathematics, Department of Mathematics and Computer Science, University of Southern Denmark, 5230 Odense M, \\ Denmark
}

\begin{abstract}
Partitioning of electron acceptors and macrofaunal bioirrigation were assessed in sediments from 4 stations along a Skagerrak-Kattegat-Belt Sea depth transect. Sediment was examined for benthic fauna composition and abundance, sediment-water fluxes $\left(\mathrm{O}_{2}\right.$, dissolved inorganic carbon [DIC], $\mathrm{NH}_{4}{ }^{+}$, and $\mathrm{NO}_{3}{ }^{-}$), anaerobic reactions (carbon oxidation $\left[\mathrm{C}_{\mathrm{ox}}\right]$, sulfate reduction $[\mathrm{SR}]$, manganese reduction $[\mathrm{MnR}]$, iron reduction $[\mathrm{FeR}]$, and ammonification $\left[\mathrm{N}_{\min }\right]$ ), porewater profiles $\left(\mathrm{O}_{2}, \mathrm{DIC}, \mathrm{SO}_{4}{ }^{2-}\right.$ and $\left.\mathrm{NH}_{4}{ }^{+}\right)$, and solid phase profiles (organic content, $\mathrm{Fe}$ and $\mathrm{Mn}$ ). Deep stations had less than half the abundance of benthic fauna than shallow stations, while the Belt Sea station was azoic due to bottom-water hypoxia. Solute fluxes and anaerobic reactions showed order-of-magnitude lower rates in sediment from deep than from shallow water. In general, anaerobic $\mathrm{C}_{\text {ox }}$ in sediments along the Skagerrak-Kattegat-Belt Sea transect is dominated by SR $(>50 \%)$ in shallow water and decreases gradually when moving into deeper water and reaches 0 at $\sim 700 \mathrm{~m}$ depth. FeR increases from 0 in shallow water to $\sim 50 \%$ at $\sim 600 \mathrm{~m}$, but rapidly reaches 0 again at $700 \mathrm{~m}$. MnR is close to 0 down to at least $500 \mathrm{~m}$ and increases to complete dominance at $700 \mathrm{~m}$. The contribution of denitrification is generally below $10 \%$ at all depths. Bioirrigationquantified as non-local exchange through diagenetic modelling -is proportional to fauna biomass and functional traits. The $\mathrm{Br}^{-}$tracer approach to determine bioirrigation on newly extracted sediment onboard a ship is not recommended. It is concluded that enhanced downward translocation of $\mathrm{O}_{2}$ into anoxic sediment through bioirrigation is the major mechanism reoxidizing subsurface metals in the deep Skagerrak and Kattegat.
\end{abstract}

KEY WORDS: Electron acceptor $\cdot$ Carbon oxidation $\cdot$ Benthic fauna $\cdot$ Bioirrigation $\cdot$ Metal oxides · Diagenetic modelling

\section{INTRODUCTION}

Biogeochemical cycles in marine sediments are driven by aerobic and anaerobic microbial processes (Canfield et al. 2005). Rates of these processes are controlled by a number of key physical, chemical and biological factors, including reactivity and burial of organic matter and solid electron acceptors by accretion and biogenic reworking, as well as supply of dissolved electron acceptors (e.g. $\mathrm{O}_{2}, \mathrm{NO}_{3}{ }^{-}$, and $\mathrm{SO}_{4}{ }^{2-}$ ) and removal of inhibitory metabolites (e.g. $\mathrm{NH}_{4}{ }^{+}$and

${ }^{*}$ Corresponding author: ebk@biology.sdu.dk
$\mathrm{H}_{2} \mathrm{~S}$ ) by solute diffusion, advection, and bioirrigation (Kristensen et al. 2012, Aller 2014). Some of these factors may appear independent at first glance (e.g. particle burial versus solute transport), but they are in fact all coupled through transport-reaction processes within the sediment matrix.

The burial rate of organic matter into oceanic sediments undisturbed by benthic fauna is typically $<1 \mathrm{~cm}$ $\mathrm{yr}^{-1}$ (Van Weering et al. 1987, Schimmelmann et al. 2016). Faunal reworking enhances this process considerably; particularly within the upper $6-10 \mathrm{~cm}$ of

(C) The authors 2018. Open Access under Creative Commons by Attribution Licence. Use, distribution and reproduction are unrestricted. Authors and original publication must be credited. 
sediments (DeMaster et al. 1985, Boudreau 1998, Teal et al. 2008). The fate of sedimentary organic matter is therefore largely controlled by microbial processes in a subsurface chemical environment, where reactions strongly depend on the delivery of electron acceptors (Meile et al. 2005, van de Velde \& Meysman 2016). The ultimate electron acceptor in sediments underlying an oxic water column is $\mathrm{O}_{2}$, but much organic carbon oxidation in reality occurs away from the oxic zone by anaerobic processes using other oxidized compounds $\left(\mathrm{NO}_{3}{ }^{-}, \mathrm{Mn}(\mathrm{IV}), \mathrm{Fe}(\mathrm{III})\right.$, and $\mathrm{SO}_{4}{ }^{2-}$ ) as electron acceptors (Canfield et al. 2005). Although the aptitude to accept electrons and thus the energy output from oxidation processes varies among electron acceptors, their quantitative role for the total carbon oxidation is primarily controlled by their availability.

Most burrow-dwelling macrofauna ventilate their burrows and thereby cause marked bioirrigation, which strongly affects transport conditions within sediments (Kristensen et al. 2012). Thus, bioirrigation may enhance solute transport by up to an order of magnitude relative to molecular diffusion. The actual extent of the enhancement depends primarily on functional traits of the infauna and sediment type (Kristensen 2001, Meysman et al. 2006, Shull et al. 2009). Bioirrigation usually decreases in an exponential fashion with depth in the sediment (Martin \& Banta 1992, Meile et al. 2001, Forster et al. 2003) in accordance with the declining depth distribution of benthic fauna (Dauwe et al. 1998, Weissberger et al. 2008).

While dissolved electron acceptors, e.g. $\mathrm{NO}_{3}{ }^{-}$and $\mathrm{SO}_{4}{ }^{2-}$, are delivered through diffusive and bioirrigation-driven advective solute transport in the sediment porewater, oxidized metals utilized as electron acceptors are solid in form. Hence, they cannot be transported downward by diffusion, and must be buried as solids through sediment accretion or biogenic reworking (Aller 1990). Alternatively, the reduced $\mathrm{Mn}^{2+}$ and $\mathrm{Fe}^{2+}$ forms can be oxidized within the subsurface sediment by $\mathrm{O}_{2}$ translocated into macrofauna burrows (Kostka et al. 2002). Thus, Mn(IV) and Fe(III) are unimportant electron acceptors in laminated sediments, but they are typically dominant in bioturbated deposition areas with high availability and recycling efficiency (Thamdrup 2000, Vandieken et al. 2006).

Studies of sediment bioirrigation usually estimate pore-water transport from tracer profiles. Conservative tracers such as bromide or tracers with known reaction kinetics such as ${ }^{222} \mathrm{Rn}$ are often used for this purpose (Martin \& Banta 1992, Forster et al. 2003, Shull et al. 2009). Also, profiles of reactive dissolved compounds such as $\mathrm{CO}_{2}$ and $\mathrm{NH}_{4}{ }^{+}$have been used to assess bioirrigation given that the depth distribution of reaction rates is known (Meile et al. 2005). Several transport-reaction models can be applied for this purpose (Boudreau 1997). Bioirrigation can be modeled as enhanced diffusion, but non-local exchange describes the process better when burrow ventilation moves solutes rapidly over long distances within the sediment and/or induces advective flow or radial diffusion across burrow walls (Kristensen \& Hansen 1999, Meysman et al. 2006, Shull et al. 2009).

The objectives of this study were to assess microbial carbon oxidation and macrofaunal bioirrigation in the upper $20 \mathrm{~cm}$ of the sediment along a Skagerrak-Kattegat-Belt Sea depth transect. Emphasis was on (1) the role of bioirrigation by macrofauna communities for the distribution of reactions and solutes in the sediment and (2) the partitioning of electron acceptors $\left(\mathrm{O}_{2}, \mathrm{NO}_{3}{ }^{-}, \mathrm{Mn}(\mathrm{IV}), \mathrm{Fe}(\mathrm{III})\right.$, and $\left.\mathrm{SO}_{4}{ }^{2-}\right)$ for carbon oxidation. The examined area is well-studied with respect to sediment biogeochemistry (e.g. Canfield et al. 1993a,b, Thamdrup et al. 1994, Rysgaard et al. 2001) and benthic fauna distribution (e.g. Rosenberg 1995, Rosenberg et al. 1996, Dauwe et al. 1998) through a number of cruises over the years. However, no studies have yet determined in detail the magnitude and biogeochemical impact of bioirrigation caused by macrobenthic burrow ventilation.

\section{MATERIALS AND METHODS}

\section{Study area and fauna sampling}

Samplings were done in late August and early September 2014 on board the R/V Aurora at 4 stations in the Skagerrak-Kattegat-Belt Sea area (Fig. 1). Stations AU1 $\left(58^{\circ} 6.21^{\prime} \mathrm{N}, 9^{\circ} 49.35^{\prime} \mathrm{E}\right)$ and AU2 $\left(58^{\circ} 2.96^{\prime} \mathrm{N}, 9^{\circ} 7.46^{\prime} \mathrm{E}\right)$ were located at 586 and $318 \mathrm{~m}$ water depth, respectively, in areas of Skagerrak where the sediment is known to be rich in iron and manganese (Canfield et al. 1993a,b). AU3 $\left(57^{\circ} 48.39^{\prime} \mathrm{N}, 11^{\circ} 3.19^{\prime} \mathrm{E}\right)$ was located at $45 \mathrm{~m}$ water depth in a deposition area of the northern Kattegat where the sediment is affected by intensive bioturbation, mostly due to brittle stars (Rosenberg 1995, Jensen et al. 2003); whereas AU4 $\left(55^{\circ} 0.26^{\prime} \mathrm{N}\right.$, $10^{\circ} 6.49^{\prime} \mathrm{E}$ ) was located at $38 \mathrm{~m}$ water depth in an area of the southern Little Belt where benthic fauna is suppressed by frequent and recent $\mathrm{O}_{2}$ deficiency in the bottom water (HELCOM 2003).

All sediment from 3 box cores $(40 \times 40 \times 60 \mathrm{~cm})$ sampled at each station was sieved through a $1 \mathrm{~mm}$ mesh on deck for fauna quantification. The material 


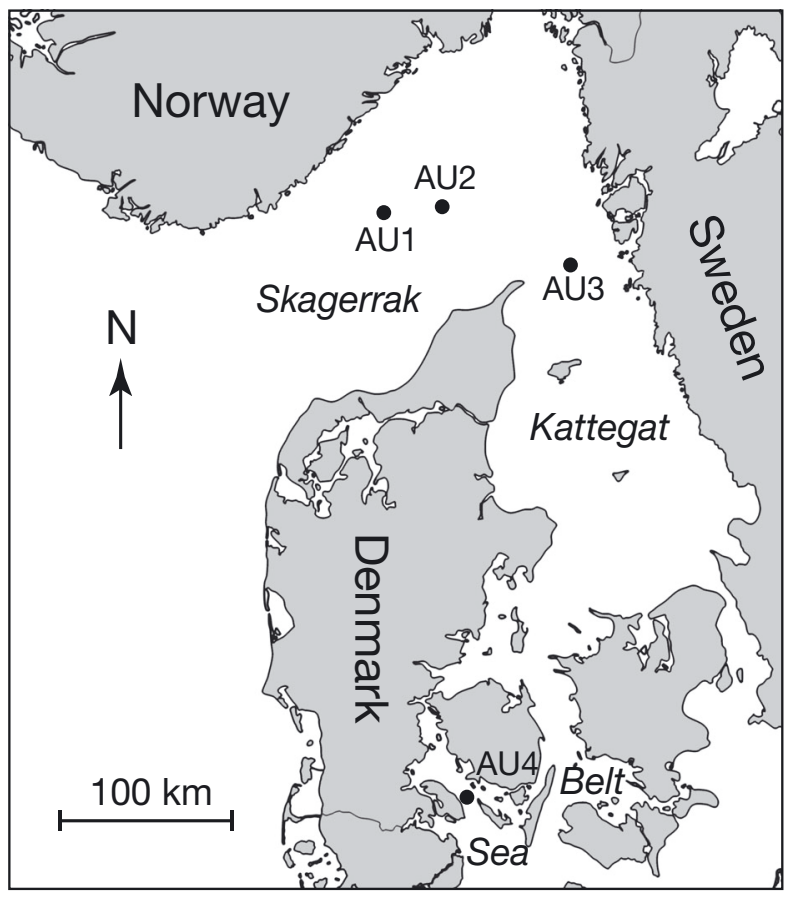

Fig. 1. Map of the Skagerrak-Kattegat-Belt Sea area surrounding Denmark. The 4 examined stations are indicated

retained from each box core was preserved in $4 \%$ formaldehyde on board, and later in the laboratory sorted carefully to separate preserved benthic animals from organic and inorganic debris. Recovered animals were stored in $70 \%$ ethanol for later identification to lowest possible taxon and for counting. The fauna was also classified into functional groups according to mobility and feeding behavior. Unfortunately, no biomass was determined due to loss of samples during a major laboratory renovation.

\section{Flux measurements}

Four box cores were sampled at each station for ondeck flux incubations and vertical sediment profiling. One sediment sub-core was taken with an acrylic glass core liner $(33 \mathrm{~cm}$ long and $8 \mathrm{~cm}$ diameter) to about $20 \mathrm{~cm}$ depth from each box core; leaving space for $\sim 10 \mathrm{~cm}$ of overlying water. The cores were inspected for traces of bioirrigation (i.e. excessive depth distribution of oxidized sediment), and placed with open tops in a $50 \mathrm{l}$ tank filled with bottom water from the respective sampling sites. Temperature, salinity and $\mathrm{O}_{2}$ were maintained at levels similar to those recorded near the bottom by the ship's CTD (Table 1). Use of bottom water assured the correct salinity, while in situ temperature was kept $\left( \pm 1^{\circ} \mathrm{C}\right)$ by thermostatted cooling. Since $\mathrm{O}_{2}$ in the bottom water
Table 1. Bottom water characteristics at the 4 stations along the examined Skagerrak-Kattegat-Belt Sea depth transect in late August and early September 2014. Numbers in parentheses for $\mathrm{O}_{2}$ indicate air saturation (\%)

\begin{tabular}{|lrrrrr|}
\hline Station & $\begin{array}{c}\text { Depth } \\
(\mathrm{m})\end{array}$ & Salinity & $\begin{array}{c}\text { Temperature } \\
\left({ }^{\circ} \mathrm{C}\right)\end{array}$ & $\begin{array}{c}\mathrm{O}_{2} \\
(\mu \mathrm{M})\end{array}$ & $\begin{array}{c}\mathrm{NO}_{3}^{-} \\
(\mu \mathrm{M})\end{array}$ \\
\hline AU1 & 586 & 35.0 & 5.9 & $245(79 \%)$ & 12.3 \\
AU2 & 318 & 35.0 & 9.0 & $250(87 \%)$ & 12.5 \\
AU3 & 45 & 33.3 & 17.2 & $246(100 \%)$ & 2.6 \\
AU4 & 38 & 24.6 & 12.5 & $95(33 \%)$ & 8.1 \\
\hline
\end{tabular}

at AU1-3 was close to air saturation, no special efforts were necessary to adjust the $\mathrm{O}_{2}$ level. The tank was in these cases simply stirred by aeration with compressed air. Aeration for AU4 was performed with a $\mathrm{N}_{2}$ /air mixture to obtain an $\mathrm{O}_{2}$ level close to $33 \%$ of air saturation, as measured in the bottom water of this site. The cores were left in darkness to rest for $4 \mathrm{~h}$ before initiating flux incubations. Water circulation inside the core liners was assured by an external rotating magnet $(60 \mathrm{rpm})$ driving internal magnetic stirring bars placed in the overlying water phase of each core.

Fluxes of $\mathrm{O}_{2}$ (total oxygen uptake, TOU), dissolved inorganic carbon (DIC: $\mathrm{CO}_{2}+\mathrm{HCO}_{3}{ }^{-}+\mathrm{CO}_{3}{ }^{2-}$ ), $\mathrm{NH}_{4}{ }^{+}$, and $\mathrm{NO}_{3}{ }^{-}$across the sediment-water interface were determined from $18 \mathrm{~h}$ (AU1), $13 \mathrm{~h}$ (AU2), $9 \mathrm{~h}$ (AU3) and $2 \mathrm{~h}$ (AU4) dark incubations. The cores were sealed with acrylic glass lids during flux incubations while maintaining water stirring. $\mathrm{O}_{2}$ was analyzed at the start and end by a fiber-optic $\mathrm{O}_{2}$ dipping probe connected to a Microx 4 (PreSens) oxygen meter through an otherwise sealed port in the lids. Initial and final water samples were taken through the port in the lids as well. Subsamples for DIC were preserved with $50 \mu \mathrm{l}$ of saturated $\mathrm{HgCl}_{2}$ in $5 \mathrm{ml}$ glass Exetainers (Labco) and stored at $5^{\circ} \mathrm{C}$ until analysis by the flow injection/diffusion cell technique (Hall \& Aller 1992). Subsamples for $\mathrm{NH}_{4}{ }^{+}$and $\mathrm{NO}_{3}{ }^{-}$were $\mathrm{GF} / \mathrm{F}$ filtered and stored frozen $\left(-20^{\circ} \mathrm{C}\right)$ in $20 \mathrm{ml}$ plastic vials until analysis on a Quickchem 8500 Flow Injection Analyzer (Lachat Instruments) according to the protocols of Bower \& Holm-Hansen (1980) for $\mathrm{NH}_{4}{ }^{+}$and Armstrong et al. (1967) for $\mathrm{NO}_{3}{ }^{-}$. Fluxes were calculated from the difference between initial and final water concentrations.

\section{Porewater and solid phase profiles}

When flux measurements were terminated, $\mathrm{Br}^{-}$ $(\mathrm{NaBr})$ was added to the tank water at a concentration of $\sim 10 \mathrm{mM}$ for determination of bioirrigation in 
flux cores. Cores were incubated in the $\mathrm{Br}^{-}$enriched water with open tops for 1 to $2 \mathrm{~d}$ before porewater extraction and solid phase analyses. Cores were sliced into $1 \mathrm{~cm}$ intervals to $4 \mathrm{~cm}$ depth followed by $2 \mathrm{~cm}$ intervals to $18 \mathrm{~cm}$ depth (slices 6-8, 10-12 and 14-16 cm were discarded). Porewater was extracted by centrifuging half of each slice in $50 \mathrm{ml}$ centrifuge tubes at $1200 \times g$ for $10 \mathrm{~min}$. The supernatant was GF/F filtered and separated into subsamples. Of these, $1 \mathrm{ml}$ was stored in Eppendorf tubes and preserved with $10 \mu$ l saturated $\mathrm{HgCl}_{2}$ for later DIC analysis as described above, $1 \mathrm{ml}$ was stored at $5^{\circ} \mathrm{C}$ for later $\mathrm{Br}^{-}, \mathrm{Cl}^{-}$and $\mathrm{SO}_{4}{ }^{2-}$ analysis by ion chromatography (ICS-2000, Dionex) and the rest (>3 ml) was stored frozen for later $\mathrm{NH}_{4}{ }^{+}$analysis as described above.

Supplementary cores were sampled using a $100 \mathrm{~cm}$ long Rumohr corer (8 cm diameter) to test if $2 \mathrm{~d}$ onboard handling of flux cores before porewater extraction impacted the results. Porewater from Rumohr cores was extracted immediately after sampling by inserting Rhizons (Rhizosphere Research) into predrilled holes at $10 \mathrm{~cm}$ intervals in the upper $30 \mathrm{~cm}$ of the core-liner. The extracted porewater was analyzed for $\mathrm{DIC}, \mathrm{SO}_{4}{ }^{2-}$ and $\mathrm{NH}_{4}{ }^{+}$as described above.

Solid phase parameters were determined on sediment subsamples from core sectioning. Wet density of sediment from each slice was measured as the wet weight (ww) of a known sediment volume. Subsequently, subsamples were analyzed for water content by drying at $100^{\circ} \mathrm{C}$ for $24 \mathrm{~h}$. The dried sediments were acidified with $\mathrm{HCl}$ fumes to remove inorganic carbon and analyzed for organic $\mathrm{C}$ and $\mathrm{N}$ content with an elemental analyzer (Flash EA 2000 Series, Thermo Analytical). Reactive solid phase Fe and Mn were obtained by extracting 100-300 mg fresh sediment subsamples in $5 \mathrm{ml}$ of $0.5 \mathrm{M} \mathrm{HCl}$ for $30 \mathrm{~min}$ under frequent shaking followed by centrifugation at $1200 \times g$ for $10 \mathrm{~min}$ (Lovley \& Phillips 1987). The supernatant was stored at $5^{\circ} \mathrm{C}$ until analysis for Fe(II) and total Fe by transferring $50 \mu \mathrm{l}$ subsamples to $2 \mathrm{ml}$ of $0.02 \%$ Ferrozine solution without and with $1 \%$ of the reducing agent hydroxylamine $\left(10 \mathrm{~g} \mathrm{l}^{-1}\right)$, respectively. All solutions were analyzed spectrophotometrically at $562 \mathrm{~nm}$, and reactive amorphous Fe(III) was operationally defined as the difference between total extractable $\mathrm{Fe}$ and $\mathrm{Fe}(\mathrm{II}) . \mathrm{Mn}^{2+}$ in the extracts was analyzed by flame atomic absorption spectrometry (AAnalyst 100, Perkin Elmer).

$\mathrm{NH}_{4}{ }^{+}$adsorption coefficients $\left(K_{\mathrm{NH} 4}\right)$ were determined according to Holmboe \& Kristensen (2002). Briefly, a series of sediment slurries ( $6 \mathrm{~g}$ sediment mixed with $30 \mathrm{ml}$ seawater), with $\mathrm{NH}_{4}{ }^{+}$adjusted to about $0,1,2$ and $4 \mathrm{mM}$ for each sediment type, were incubated in the dark for $2 \mathrm{~d}$ before centrifugation at $1200 \times g$ for $10 \mathrm{~min}$. The supernatant was GF/F filtered and stored frozen $\left(-20^{\circ} \mathrm{C}\right)$ until $\mathrm{NH}_{4}{ }^{+}$analysis as previously described. The centrifuged sediment was homogenized, and exchangeable $\mathrm{NH}_{4}{ }^{+}$was extracted by transferring $2 \mathrm{~g}$ sediment subsamples to $5 \mathrm{ml}$ of $2 \mathrm{M} \mathrm{KCl}$ for $30 \mathrm{~min}$ at $5^{\circ} \mathrm{C}$ followed by centrifugation at $1200 \times g$ for $10 \mathrm{~min}$. The supernatant was GF/F filtered and stored frozen $\left(-20^{\circ} \mathrm{C}\right)$ until $\mathrm{NH}_{4}{ }^{+}$analysis as described above. The dimensionless linear adsorption coefficient, $K_{\mathrm{NH} 4}$ was calculated according to Krom \& Berner (1980), where $K_{\mathrm{NH} 4}$ is the slope from a plot of extracted $\mathrm{NH}_{4}{ }^{+}$vs. porewater $\mathrm{NH}_{4}{ }^{+}$.

\section{$\mathrm{O}_{2}$ microprofiles}

Vertical microprofiles of $\mathrm{O}_{2}$ were measured on subcores taken from box cores using polycarbonate core liners (25 cm long and $5 \mathrm{~cm}$ diameter). Cores were stored on deck at in situ $\mathrm{O}_{2}$ and temperature for 1-5 h before measurements. Since preliminary profiles from AU4 showed $\mathrm{O}_{2}$ depletion at the sedimentwater interface, no further $\mathrm{O}_{2}$ microprofiles were made at this station. Microprofiles at the other stations were measured using custom-built Clarke-type microelectrodes with internal reference and guard (Revsbech 1989). Two to 4 profiles were measured on each of 2 to 3 cores from each station.

\section{Anoxic incubations}

Vertical profiles of anaerobic carbon oxidation $\left(\mathrm{C}_{\mathrm{ox}}\right)$, sulfate reduction (SR), manganese reduction $(\mathrm{MnR})$, iron reduction (FeR), and ammonification $\left(\mathrm{N}_{\min }\right)$ were quantified by closed anoxic incubations. Sediment remaining from the depths $0-2,2-4,8-10$ and $16-18 \mathrm{~cm}$ after slicing the 4 flux cores at each station was immediately used for the anoxic incubations. The sediment slices from each depth interval were pooled (a total of $\sim 200 \mathrm{ml}$ ), homogenized and transferred in air into eight $20 \mathrm{ml}$ glass scintillation vials (jars). Rapid handling (few minutes) assured limited oxidation of the sediment. The jars were then sealed gas-tight without headspace to prevent $\mathrm{O}_{2}$ intrusion, and incubated in darkness at in situ temperatures (see Table 1).

Two jars from each depth were sacrificed at $7 \mathrm{~d}$ (AU4) to $20 \mathrm{~d}$ (AU1) intervals for determination of changes in porewater DIC, $\mathrm{SO}_{4}{ }^{2-}$, and $\mathrm{NH}_{4}{ }^{+}$concentrations, as well as solid phase Mn, Fe(II), and Fe(III). Porewater was extracted by centrifuging the jars at 
$1200 \times g$ for $10 \mathrm{~min}$. The GF/F filtered porewater subsamples were handled and analyzed for DIC, $\mathrm{SO}_{4}{ }^{2-}$ and $\mathrm{NH}_{4}{ }^{+}$as described above. The sediment remaining after porewater extraction was analyzed for reactive $\mathrm{Mn}, \mathrm{Fe}(\mathrm{II})$ and $\mathrm{Fe}(\mathrm{III})$ as described above. The majority of extracted Mn was assumed to be reactive $\mathrm{Mn}(\mathrm{IV})$ available for microbial reduction (Kristiansen et al. 2002). Reaction rates $\left(C_{o x}, S R R\right.$, and $\left.N_{\min }\right)$ in $\mathrm{nmol} \mathrm{cm} \mathrm{d}^{-1}$ were calculated from a linear fit of concentration changes in the time series of samples. $\mathrm{N}_{\min }$ was corrected for adsorption, using the appropriate $K_{\mathrm{NH} 4}$ values as described above. MnR and FeR were determined as solid-phase reactive $\mathrm{Mn}$ (IV) and Fe(III) depletion over time.

\section{Data analysis}

Pielou's evenness, based on the Shannon diversity index, was used to describe how numerically equal the species in the benthic fauna communities were at the examined sampling stations (Heip et al. 1998):

$$
\begin{aligned}
& \text { Shannon diversity: } \quad H^{\prime}=-\sum_{i=1}^{R} p_{i} \ln p_{i} \\
& \text { Pielou's evenness: } \quad J^{\prime}=\frac{H^{\prime}}{H_{\max }^{\prime}}=\frac{H^{\prime}}{\ln R}
\end{aligned}
$$

where $p_{i}$ is the proportional abundance of species $i_{\text {, }}$ and $R$ is the species richness.

Bioirrigation in flux cores on board the ship was determined from vertical $\mathrm{Br}^{-}$profiles by a 1D diffusion model using transient transport equations (Martin \& Banta 1992, Forster et al. 2003) with exponentially decreasing non-local transport in the bioturbated zone (zone 1: $0 \leq x \leq L_{1}$ ):

$$
\frac{\partial C_{1}}{\partial t}=D_{s} \frac{\partial^{2} C_{1}}{\partial x^{2}}-\alpha_{0} \mathrm{e}^{-b x}\left(C_{1}-C_{0}\right)
$$

and diffusive transport below this depth (zone 2: $L_{1} \leq$ $\left.x \leq L_{2}\right)$ :

$$
\frac{\partial C_{2}}{\partial t}=D_{s} \frac{\partial^{2} C_{2}}{\partial x^{2}}
$$

where $C_{0}$ is the concentration of $\mathrm{Br}^{-}$in the overlying water $(\mathrm{mM}) ; C_{1}$ and $C_{2}$ are the $\mathrm{Br}^{-}$concentrations in the porewater $(\mathrm{mM})$ at depth $x$ of zone 1 and zone $2 ; L_{1}$ is the depth of the bioturbated zone $(\mathrm{cm})$ and $L_{2}$ is the depth of total sediment column $(20 \mathrm{~cm}) ; D_{s}$ is the sediment diffusion coefficient $\left(\mathrm{cm}^{2} \mathrm{~d}^{-1}\right)$ after correction of molecular diffusion for porosity (Li \& Gregory 1974); $\alpha_{0}$ is the non-local transport coefficient $\left(\mathrm{d}^{-1}\right)$ at $x=0$; and $b$ is the attenuation coefficient $\left(\mathrm{cm}^{-1}\right)$ of non-local exchange within the bioturbated zone. The initial and boundary conditions are:

$$
\begin{gathered}
t=0,0<x<L_{2}, C_{1}=C_{2}=C_{\text {initial }} \\
t>0, x=0, C_{1}=C_{0} \\
t>0, x=L_{1}, \frac{\partial C_{1}}{\partial x}=\frac{\partial C_{2}}{\partial x} \text { and } C_{1}=C_{2} \\
t>0, x=L_{2}, \frac{\partial C_{2}}{\partial x}=0
\end{gathered}
$$

where $C_{\text {initial }}$ is the background porewater $\mathrm{Br}^{-}$concentration before any transport occurs. The equations were solved in MATLAB using a finite element code by first applying a Galerkin approximation in space (Skeel \& Berzins 1990) and then time integration with a variable-step, variable-order solver based on numerical differentiation formulas of orders 1 to 5 (Shampine \& Reichelt 1997, Shampine et al. 1999). Finally, the constants $\alpha_{0}, b$ and $L_{1}$ were determined by fitting, using a trust-region-reflective least-squares algorithm (Coleman \& Li 1994, 1996) to minimize the sum of square errors for the measured pairs.

A double-exponential decay model was used to describe the depth-dependent reaction pattern determined by the anoxic jar incubations. The total reactive organic pool $\left(G_{T}\right)$ in the sediment was assumed to be divided into 2 decomposable fractions. Accordingly, a 2- $G$ depth-dependent approach $\left(\frac{\mathrm{d} G_{T}}{\mathrm{~d} x}\right.$, Westrich \& Berner 1984) should be capable of describing the diagenesis. Each fraction diminishes with depth in the sediment at a rate defined by the product of its concentration and first-order depth attenuation constant (Boudreau 1997). The total organic matter degradation is then equal to the sum of the $2-G$ depthdependent rates according to:

$$
\frac{\mathrm{d} G_{T}}{\mathrm{~d} x}=-\mathrm{a}_{1} G_{1}-a_{2} G_{2} \quad\left(\mathrm{nmol} \mathrm{cm}^{-3} \mathrm{~cm}^{-1}\right)
$$

where $a_{1}$ and $a_{2}$ are the down-core attenuation constants $\left(\mathrm{cm}^{-1}\right)$, and $x$ is depth in the sediment $(\mathrm{cm})$. Pool sizes $(G)$ can be substituted with reaction rates $\left(R=\frac{\mathrm{d} G}{\mathrm{~d} t}\right)$ by transforming Eq. (5) into:

$$
R(x)=R_{1} \mathrm{e}^{-a_{1} x}+R_{2} \mathrm{e}^{-a_{2} x} \quad\left(\mathrm{nmol} \mathrm{cm}{ }^{-3} \mathrm{~d}^{-1}\right)
$$

where $R(x)$ is the total reaction rate at depth $x_{1} R_{1}$ is the rate of the fast pool at depth $x=0$, and $R_{2}$ is the rate of the slow pool at depth $x=0$. The down-core attenuation constant is in reality the first-order decay constant $\left(\mathrm{d}^{-1}\right)$ divided by the burial velocity, or sedimentation rate $\left(\omega_{;} \mathrm{cm} \mathrm{d}^{-1}\right)$. Diagenetic reactions involving DIC, $\mathrm{SO}_{4}{ }^{2-}$ and $\mathrm{NH}_{4}{ }^{+}$derived from the anoxic 
incubations were fitted to Eq. (6) to obtain the depth attenuation of $\mathrm{C}_{\mathrm{ox}}, \mathrm{SR}, \mathrm{N}_{\min }$ in sediments at the selected stations along the Skagerrak-Kattegat-Belt Sea depth transect.

Solutes consumed or generated in sediments by the 2- $G$ depth-dependent diagenetic reactions (e.g. DIC, $\mathrm{SO}_{4}{ }^{2-}$, and $\mathrm{NH}_{4}{ }^{+}$) are subject to transport by molecular diffusion, advection, and mixing processes caused by physical or biogenic activity. By assuming steady state and ignoring sedimentation, the concentration of any solute, $C(x, t)$, in the porewater $(\mathrm{mM})$ can be described by the classic 1D diffusion-reaction model of Berner (1980). However, in the presence of bioturbating infauna the model must be modified to account for the enhanced, but with depth exponentially decreasing, bioirrigation transport induced by fauna ventilation. A transport-reaction model with a non-local exchange module for use in bioirrigated sediments was applied here according to the 2-layer formalism of Aller (1982).

For $0<x<L_{1}$ :

$\frac{\partial C_{1}}{\partial t}=\frac{D_{s}}{(1+K)} \frac{\partial^{2} C_{1}}{\partial x^{2}}-\alpha_{0} \mathrm{e}^{-b x}\left(C_{1}-C_{0}\right)+R_{1} \mathrm{e}^{-\alpha_{1} x}+R_{2} \mathrm{e}^{-a_{2} x}=0$

For $L_{1}<x<\infty$ :

$$
\frac{\partial C_{2}}{\partial t}=\frac{D_{s}}{(1+K)} \frac{\partial^{2} C_{2}}{\partial x^{2}}+R_{1} \mathrm{e}^{-a_{1} X}+R_{2} \mathrm{e}^{-a_{2} X}=0
$$

The boundary conditions are:

$$
\begin{gathered}
x=0, C=C_{0} \\
x=L_{1}, \frac{\partial C_{1}}{\partial x}=\frac{\partial C_{2}}{\partial x} \text { and } C_{1}=C_{2} \\
x=\infty, \frac{\partial C_{2}}{\partial x}=0
\end{gathered}
$$

The constants $D_{s}$ (sediment diffusion coefficient), $K$ (dimensionless adsorption coefficient), $C_{0}$ (overlying water concentration), $R_{1}, R_{2}, a_{1}, a_{2}$ (reaction rates and attenuation coefficients), and $L_{1}$ (visually detected depth of bioirrigation) were derived from the above analyses and modelling, while the unknown constants $\alpha_{0}$ (non-local transport coefficient at the sediment-water interface) and $b$ (depth attenuation constant for non-local exchange) were determined from best fit of the model to measured porewater profiles. The differential equations were solved in MATLAB with a finite difference code that implemented the 3-stage Lobatto IIIa formula (Kierzenka \& Shampine 2001). The constants $\alpha_{0}$ and $b$ were then determined by fitting, using a trust-region-reflective least-squares algorithm (Coleman \& Li 1994, 1996) to minimize the sum of square errors for the measured pairs.

\section{RESULTS}

\section{Fauna composition}

The deep Skagerrak stations (AU1-2) had less than half the abundance of benthic fauna than the roughly 2100 ind. $\mathrm{m}^{-2}$ found at the shallower Kattegat station (AU3) (Table 2). The Belt station (AU4), on the other hand, was azoic due to recent episodes of bottom-water $\mathrm{O}_{2}$ deficiency. The species richness ranged from 17 at AU1 to 28 at AU2. Pielou's evenness was higher at AU2 than AU1 and AU3 due to distinct dominance of 1 (Spiochaetopterus typicus, $>50 \%$ ) or 2 (Amphiura filiformis, $>50 \%$, and Kurtiella bidentata, $>30 \%$ ) species, respectively, at the latter stations. The partitioning of taxa varied considerably, with dominance of polychaetes $(>60 \%)$ at AU1, molluscs $(\sim 80 \%)$ at AU2, and echinoderms $(>50 \%)$ at AU3. The predominant species also governed the partitioning of feeding types, as for example the subsurface deposit-feeding Thyasira equalis and Yoldiella lucida almost exclusively accounted for the $>60 \%$ occurrence of this feeding type at AU2. Similarly, the dominant species at AU1 and AU3 were responsible for the high level of suspensionfeeding (>60 and $>90 \%$, respectively) at these stations. Conversely, neither the taxa nor the feeding types seem to influence the bioturbation types. Gallery- or tube-forming species were most common $(>60 \%)$ at AU1, whereas surficial burrowers dominated at AU2 (>80\%) and AU3 ( 100\%). It should be noted, however, that the deep-burrowing and gallery-forming ghost shrimp Callianassa tyrrhena was present at AU3 with a minimum density $( \pm \mathrm{SD})$ of $16 \pm 4$ ind. $\mathrm{m}^{-2}$.

The unfortunate lack of biomass determination in the present study was compensated using literature values from the same area. Rosenberg (1995) and Rosenberg et al. (1996) quantified the benthic fauna at 23 stations in Skagerrak from 69 to $682 \mathrm{~m}$ water depth. Based on their data on abundance and biomass, the average individual biomass decreases with water depth according to the following equation:

$$
W=89.12 \times \mathrm{e}^{(-3.75 \times d)}, \mathrm{r}^{2}=0.573
$$

where $W$ is weight (mg ww) and $d$ is water depth (m). Accordingly, the individual biomass at AU1-3 was estimated to 10,27 and $75 \mathrm{mg} \mathrm{ww}$, respectively, resulting in a total biomass increase with decreasing depth from 8 to $159 \mathrm{~g} \mathrm{ww} \mathrm{m}^{-2}$ at the 3 sampling stations (Table 2). 
Table 2. Abundance $( \pm \mathrm{SD})$, biomass and species richness $( \pm \mathrm{SD})$ as well as Pielou's evenness $\left(J^{\prime}\right)$ for benthic fauna at the 4 sampling stations along the SkagerrakKattegat-Belt Sea depth transect. The abundance is partitioned into: (1) Major taxonomic groups (Polychaeta, Mollusca, Crustacea and Echinodermata) with indications of the 2 most dominant species. (2) Feeding types (SF: suspension feeder; SDF: surface deposit-feeder; SSDF: subsurface deposit-feeder; P: predator). (3) Bioturbation types (SB: surficial burrower $[<5 \mathrm{~cm}]$; GB: gallery/tube burrower $[>5 \mathrm{~cm}]$ ). ww: wet weight; -: no fauna present

\begin{tabular}{|c|c|c|c|c|}
\hline & AU1 & AU2 & AU3 & AU4 \\
\hline Total abundance $\left(\mathrm{m}^{-2}\right)$ & $775 \pm 119$ & $483 \pm 91$ & $2109 \pm 75$ & $0 \pm 0$ \\
\hline Total biomass $\left(\mathrm{g} w w \mathrm{~m}^{-2}\right)^{\mathrm{a}}$ & 7.7 & 13.0 & 158.8 & 0 \\
\hline Number of species & $28 \pm 1$ & $17 \pm 0$ & $20 \pm 0$ & $0 \pm 0$ \\
\hline Pielou's evenness & 0.55 & 0.67 & 0.41 & 0 \\
\hline \multicolumn{5}{|l|}{ (1) Taxonomic partition } \\
\hline Polychaeta (\%) & 65.6 & 18.5 & 3.7 & 0 \\
\hline Mollusca (\%) & 30.1 & 79.4 & 42.1 & 0 \\
\hline Crustacea (\%) & 2.2 & 0.4 & 1.5 & 0 \\
\hline Echinodermata (\%) & 0.2 & 2.1 & 52.4 & 0 \\
\hline Species 1 (\%) & $\begin{array}{l}\text { Spiochaetopterus } \\
\text { typicus (52.1) }\end{array}$ & $\begin{array}{c}\text { Thyasira } \\
\text { equalis (29.8) }\end{array}$ & $\begin{array}{c}\text { Amphiura } \\
\text { filiformis (52.4) }\end{array}$ & - \\
\hline Species $2(\%)$ & $\begin{array}{c}\text { Thyasira } \\
\text { equalis (13.7) }\end{array}$ & $\begin{array}{c}\text { Yoldiella } \\
\text { lucida (28.9) }\end{array}$ & $\begin{array}{c}\text { Kurtiella } \\
\text { bidentate (36.4) }\end{array}$ & - \\
\hline \multicolumn{5}{|l|}{ (2) Feeding type } \\
\hline SF (\%) & 63.1 & 0.0 & 90.2 & - \\
\hline $\operatorname{SDF}(\%)$ & 11.1 & 31.0 & 5.0 & - \\
\hline SSDF (\%) & 20.5 & 65.5 & 2.1 & - \\
\hline $\mathrm{P}(\%)$ & 5.3 & 3.5 & 2.7 & - \\
\hline \multicolumn{5}{|l|}{ (3) Bioturbation type } \\
\hline SB (\%) & 36.1 & 85.6 & 97.1 & - \\
\hline GB (\%) & 63.9 & 14.4 & 2.9 & - \\
\hline
\end{tabular}

creased with depth at all stations, primarily in the upper $6 \mathrm{~cm}$. Lowest particulate organic carbon (POC) content was observed at AU3, approaching about half the level measured at AU1 and AU2. The sediment at AU4 was soft and organic-rich mud with a density of $1.1 \mathrm{~g} \mathrm{~cm}^{-3}$. It appeared completely anoxic and sulfidic, with no oxidized sediment except for a thin $(<1 \mathrm{~mm})$ brown film at the surface. The organic $\mathrm{C}: \mathrm{N}$ ratio was slightly lower at AU2 (11-12) than at AU1 and AU3 (13-14) and higher than at AU4 (9-10). $\mathrm{NH}_{4}{ }^{+}$ adsorption coefficients $\left(K_{\mathrm{NH} 4}\right)$ were close to 1 at all stations and sediment depths, except for markedly lower values in the upper $2 \mathrm{~cm}$.

Solid-phase Fe was generally dominated by high levels of Fe(II), increasing with depth in the sediment at all stations, reaching $\sim 110, \sim 60, \sim 80$ and $\sim 90 \mu \mathrm{mol} \mathrm{cm} \mathrm{cm}^{-3}$ at AU1-4, respectively (Fig. 2). Fe(III) only surpassed Fe(II) in the upper strongly oxidized $5 \mathrm{~cm}$ at

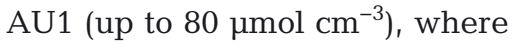
Fe(II) was close to 0. Below this depth, Fe(III) decreased to around

\section{Solid phase sediment profiles}

The sediments at AU1 and AU2 had similar appearance and consisted of primarily silt with a wet density of $\sim 1.3 \mathrm{~g}$ $\mathrm{cm}^{-3}$ (Table 3). Both sediments had a distinct brownish oxidized zone in the upper 5-10 $\mathrm{cm}$ that gradually faded 10-15 cm downcore and extended deepest at AU1. Sediment from AU1 appeared slightly muddier than that from AU2 as indicated by the higher porosity and organic content. AU3 sediment consisted mostly of fine sand with a density of $1.6-1.7 \mathrm{~g} \mathrm{~cm}^{-3}$. An oxidized zone extended to $5-6 \mathrm{~cm}$ depth at this station with occasional oxidized traces, i.e. burrows of $C$. tyrrhena, down to at least $20 \mathrm{~cm}$ depth in the sediment. Porosity and organic content of the sediment de-
Table 3. Sediment characteristics at the 4 stations along the examined Skagerrak-Kattegat-Belt Sea depth transect in late August and early September 2014. Values for 3 depth intervals are given. POC: particulate organic carbon; dw: dry weight; -: data not available

\begin{tabular}{|lcccccc|}
\hline Station & $\begin{array}{c}\text { Depth } \\
(\mathrm{cm})\end{array}$ & $\begin{array}{c}\text { Wet density } \\
\left(\mathrm{g} \mathrm{cm}^{-3}\right)\end{array}$ & Porosity & $\begin{array}{c}\text { POC } \\
(\% \text { of dw })\end{array}$ & $\begin{array}{c}\text { C:N } \\
(\mathrm{mol})\end{array}$ & $K_{\mathrm{NH} 4}$ \\
\hline AU1 & $0-1$ & - & 0.97 & 3.38 & 14.0 & 0.28 \\
& $4-6$ & 1.26 & 0.75 & 3.22 & 13.4 & 0.60 \\
& $16-18$ & 1.29 & 0.74 & 3.03 & 14.6 & 1.50 \\
AU2 & $0-1$ & - & 0.84 & 3.15 & 11.9 & 0.73 \\
& $4-6$ & 1.28 & 0.76 & 2.96 & 11.3 & 0.97 \\
& $16-18$ & 1.34 & 0.70 & 2.63 & 11.5 & 1.05 \\
AU3 & $0-1$ & - & 0.73 & 1.19 & 13.8 & 0.59 \\
& $4-6$ & 1.63 & 0.58 & 1.10 & 13.8 & 0.95 \\
& $16-18$ & 1.68 & 0.51 & 0.92 & 13.4 & 1.41 \\
AU4 & $0-1$ & - & 0.88 & 5.90 & 9.8 & 0.46 \\
& $4-6$ & 1.11 & 0.85 & 5.63 & 9.7 & 1.03 \\
& $16-18$ & 1.12 & 0.81 & 5.92 & 10.2 & 1.24 \\
\hline
\end{tabular}




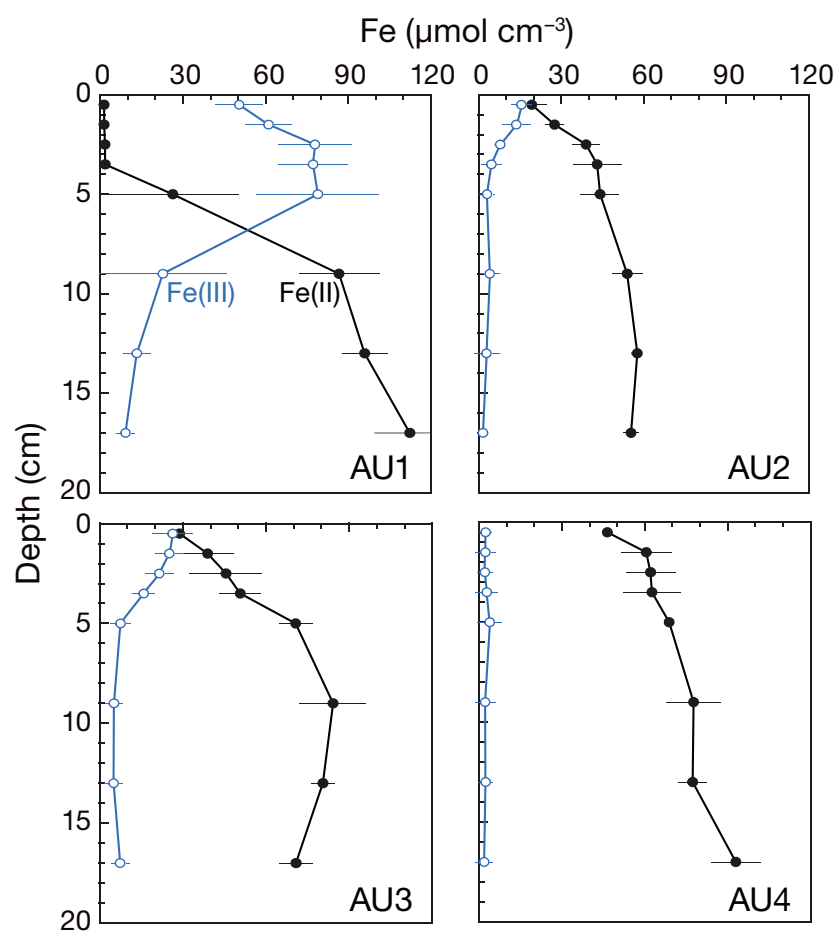

Fig. 2. Depth pattern of reactive solid phase iron (Fe(III) and $\mathrm{Fe}(\mathrm{II}))$ in the sediment at the 4 stations (AU1-4). Values are given as the average of triplicates $( \pm \mathrm{SD})$

and below $10 \mu \mathrm{mol} \mathrm{cm} \mathrm{cm}^{-3}$. The near-surface level of Fe(II) and Fe(III) was similar at AU2 and AU3 (15-20 and $25-30 \mu \mathrm{mol} \mathrm{cm}{ }^{-3}$, respectively). Fe(III) decreased rapidly within the upper $5 \mathrm{~cm}$ at these stations to trace levels at AU2, and $5-10 \mu \mathrm{mol} \mathrm{cm} \mathrm{cm}^{-3}$ at AU3. The anoxic AU4 only showed traces of Fe(III). Reactive solid Mn was high at AU1, showing an increase with depth from $\sim 10$ to $\sim 32 \mu \mathrm{mol} \mathrm{cm}{ }^{-3}$ in the upper $2-3 \mathrm{~cm}$ followed by a decrease to $\sim 20 \mu \mathrm{mol} \mathrm{cm}{ }^{-3}$ from 6 to $10 \mathrm{~cm}$ depth (Fig. 3). The other stations had only traces of

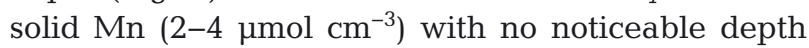
pattern.

\section{Anaerobic reaction rates and sediment-water fluxes}

Reaction rates $\left(\mathrm{C}_{\mathrm{ox}}, \mathrm{SR}\right.$, and $\mathrm{N}_{\min }$ ) obtained from the anoxic jar incubations varied among stations and generally decreased strongly with depth in the sediment (Fig. 4). $\mathrm{C}_{\mathrm{ox}}$ and SR near the sediment surface at the shallow AU3 and AU4 were an order of magnitude higher than at AU1 and 2 times higher than at AU2. The declining anaerobic rates with depth in the upper $18 \mathrm{~cm}$ of the sediment fitted well at all stations to a depth-dependent double exponential decay pattern according to Eq. (6) (Table 4). Down-core atten-

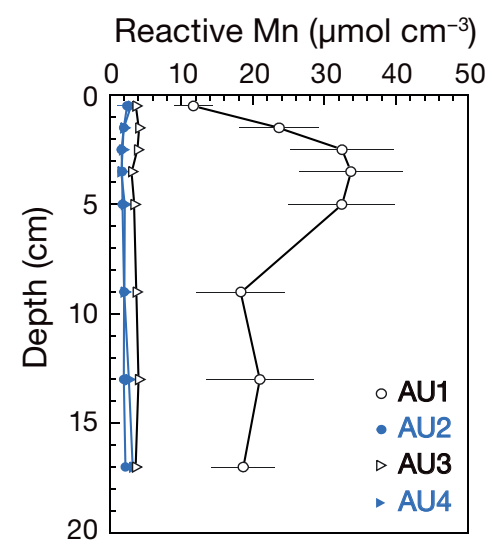

Fig. 3. Depth pattern of reactive solid phase manganese $(\mathrm{Mn})$ in the sediment at the 4 stations (AU1-4). Values are given as the average of triplicates $( \pm \mathrm{SD})$

uation of $\mathrm{C}_{\text {ox }}$, SR and $\mathrm{N}_{\text {min }}$ was generally higher at the more reactive shallow than the deep stations with rates approaching almost the same level below $15 \mathrm{~cm}$ depth at all stations. MnR and FeR behaved differently, with highest MnR at AU1 and highest FeR at AU3 (Fig. 5), followed by a strong decrease with sediment depth from about 25 and $140 \mathrm{nmol} \mathrm{cm} \mathrm{cm}^{-3}$, respectively, near the surface to $<5$ and $<30 \mathrm{nmol}$ $\mathrm{cm}^{-3} \mathrm{~d}^{-1}$ at $18 \mathrm{~cm}$ depth. MnR at AU2 was irregular and always below $10 \mathrm{nmol} \mathrm{cm} \mathrm{cm}^{-3} \mathrm{~d}^{-1}$, while MnR was almost 0 at AU3 and AU4. FeR showed similar depth attenuation at AU1 and AU2 with a level about 50 nmol cm $\mathrm{cm}^{-3} \mathrm{~d}^{-1}$ lower than AU3 at all depths. FeR was almost 0 throughout the sediment column at the anoxic AU4.

Area-specific reaction rates in the depth zone of interest were estimated by integrating Eq. (6) to $20 \mathrm{~cm}$ depth (Table 4). $\mathrm{C}_{\mathrm{ox}}$ decreased almost 10-fold with increasing water depth from AU4 to AU1, while SR decreased almost 30-fold within the same depth range. The $\mathrm{C}_{\mathrm{ox}}$ :SR ratio around 2 at AU4 indicates that carbon oxidation at that station was dominated by $\mathrm{SR}$. The high $\mathrm{C}_{\mathrm{ox}}$ :SR ratios at the other stations, particularly that of 6.9 for AU1, indicate that processes other than SR contributed to DIC production. Accordingly, the range of FeR was $4-15 \mathrm{mmol} \mathrm{m}^{-2} \mathrm{~d}^{-1}$ from AU1 to AU3, while MnR was almost 2 and $1 \mathrm{mmol} \mathrm{m}{ }^{-2} \mathrm{~d}^{-1}$ at AU1 and AU2, respectively. Almost no FeR and MnR were detected at AU4. $\mathrm{N}_{\min }$ was lowest at AU1, with area-specific rates reaching $\sim 20 \%$ of those at AU2 and AU4, and only $10 \%$ of that at AU3 (Table 4). The $\mathrm{C}_{\mathrm{ox}}: \mathrm{N}_{\min }$ ratios were close to the Redfield ratio with values ranging from 5 to 13.5 .

Solute fluxes also reflected the water depth, showing an order of magnitude lower TOU and DIC flux 

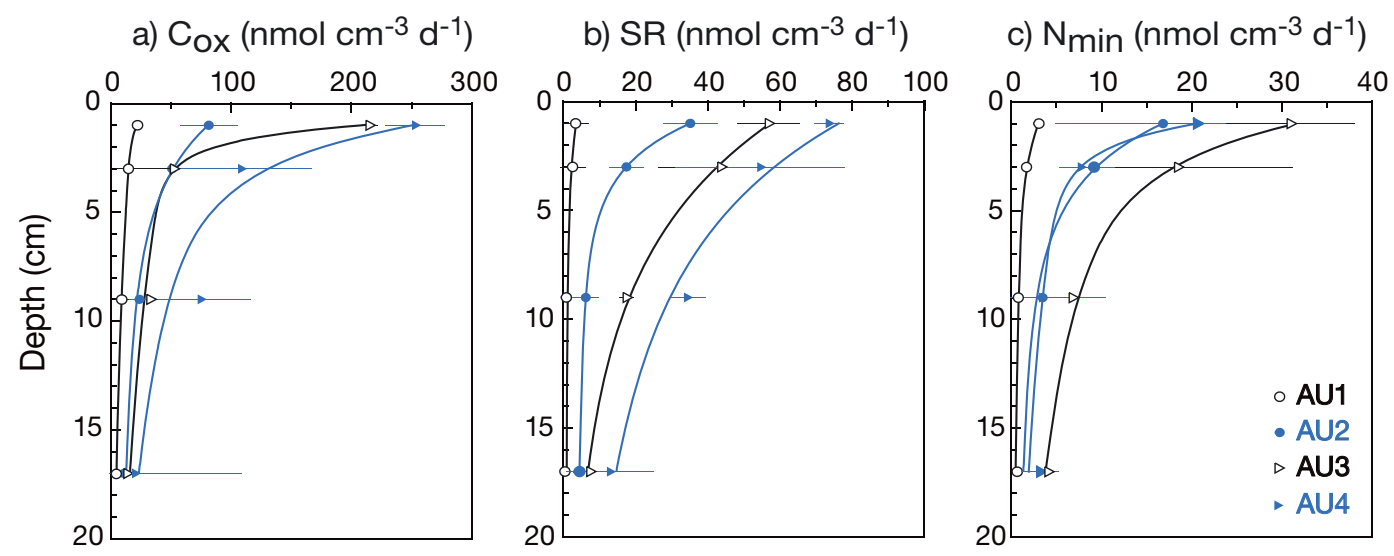

Fig. 4. Depth-dependence of (a) anaerobic $\mathrm{C}_{\mathrm{ox}}$ (dissolved organic carbon [DIC] production), (b) SR (sulfate reduction), and (c) $\mathrm{N}_{\text {min }}\left(\mathrm{NH}_{4}{ }^{+}\right.$production) in the sediment at the 4 stations (AU1-4). Symbols indicate the calculated rates (slope $\pm \mathrm{SD}, \mathrm{n}=4$ ) from anaerobic incubations and curves represent the best fit to the double-exponential model shown in Eq. (4)

Table 4. Parameters obtained by fitting down-core reactivity of carbon oxidation $\left(\mathrm{C}_{\mathrm{ox}}\right)$, sulfate reduction (SR), and ammonification $\left(\mathrm{N}_{\min }\right)$ to Eq. (6). The $0-20 \mathrm{~cm}$ depth integrated reactions $\left(\mathrm{mmol} \mathrm{m}^{-2} \mathrm{~d}^{-1}\right)$ are indicated. The $\mathrm{C}_{\mathrm{ox}}: \mathrm{N}_{\min }$ and $\mathrm{C}_{\text {ox }}$ : $\mathrm{SR}$ ratios are shown for comparison. $R_{1}$ and $R_{2}$ are given as $\mathrm{nmol} \mathrm{cm}^{-3} \mathrm{~d}^{-1} ; a_{1}$ and $a_{2}$ are given as $\mathrm{cm}^{-1}$

\begin{tabular}{|c|c|c|c|c|}
\hline & AU1 & AU2 & AU3 & AU4 \\
\hline $\mathrm{C}_{\mathrm{ox}}\left(\mathrm{r}^{2}\right)$ & 1.000 & 0.997 & 0.999 & 0.965 \\
\hline$R_{1}$ & 31.16 & 76.90 & 629.15 & 272.18 \\
\hline$a_{1}$ & 1.816 & 0.336 & 1.339 & 0.552 \\
\hline$R_{2}$ & 18.85 & 27.44 & 53.07 & 102.74 \\
\hline$a_{2}$ & 0.078 & 0.046 & 0.069 & 0.087 \\
\hline $0-20 \mathrm{~cm}$ & 1.65 & 5.21 & 10.12 & 14.67 \\
\hline $\mathrm{SR}\left(\mathrm{r}^{2}\right)$ & 0.969 & 1.000 & 0.999 & 0.983 \\
\hline$R_{1}$ & 3.18 & 45.36 & 58.44 & 50.69 \\
\hline$a_{1}$ & 0.355 & 0.478 & 0.165 & 0.202 \\
\hline$R_{2}$ & 1.25 & 7.20 & 8.18 & 37.10 \\
\hline$a_{2}$ & 0.020 & 0.029 & 0.054 & 0.062 \\
\hline $0-20 \mathrm{~cm}$ & 0.240 & 1.722 & 4.378 & 6.717 \\
\hline $\mathrm{C}_{\mathrm{ox}}: \mathrm{SR}$ & 6.88 & 3.02 & 2.31 & 2.18 \\
\hline \multicolumn{5}{|l|}{ FeR } \\
\hline $0-20 \mathrm{~cm}$ & 4.24 & 6.84 & 14.65 & 0.31 \\
\hline \multicolumn{5}{|l|}{ MnR } \\
\hline $0-20 \mathrm{~cm}$ & 1.73 & 1.12 & 0 & 0 \\
\hline $\mathrm{N}_{\min }\left(\mathrm{r}^{2}\right)$ & 0.987 & 0.994 & 0.998 & 0.996 \\
\hline$R_{1}$ & 3.56 & 19.16 & 29.74 & 35.63 \\
\hline$a_{1}$ & 1.096 & 0.368 & 0.514 & 0.910 \\
\hline$R_{2}$ & 2.04 & 3.68 & 14.76 & 6.69 \\
\hline$a_{2}$ & 0.094 & 0.061 & 0.082 & 0.074 \\
\hline $0-20 \mathrm{~cm}$ & 0.216 & 0.945 & 2.029 & 1.090 \\
\hline $\mathrm{C}_{\mathrm{ox}}: \mathrm{N}_{\min }$ & 7.64 & 5.51 & 4.99 & 13.46 \\
\hline
\end{tabular}

a) $\operatorname{MnR}\left(\mathrm{nmol} \mathrm{cm}^{-3} \mathrm{~d}^{-1}\right)$

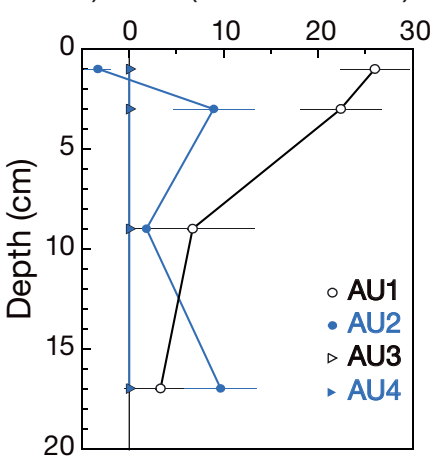

b) FeR ( $\left.\mathrm{nmol} \mathrm{cm}^{-3} \mathrm{~d}^{-1}\right)$

Fig. 5. Depth-dependence of (a) MnR (manganese reduction), and (b) FeR (iron reduction) in the sediment at the 4 stations (AU1-4). Symbols indicate the calculated rates (slope $\pm \mathrm{SD}, \mathrm{n}=4$ ) from anaerobic incubations

values in deep than in shallow water (Table 5). The respiratory quotient, RQ (ratio between DIC efflux and TOU), was highest at AU3 and lowest at AU2 and AU4 with a range of 1.4 to 2. The DIC fluxes at AU1, AU3 and AU4 (Table 5) were about 3 times higher than the depth integrated jar rates (Table 4), whereas the flux at AU2 was $20 \%$ higher than the corresponding jar rate. This discrepancy indicates that DIC efflux at AU2 for some reason may be underestimated. A slight $\mathrm{NH}_{4}{ }^{+}$uptake was evident at AU1 and AU2, while AU3 and AU4 showed a 20 to 30 -fold higher release. $\mathrm{NO}_{3}{ }^{-}$fluxes were low and erratic at AU1-3, while AU4 had a high uptake. $\mathrm{NH}_{4}{ }^{+}$ $+\mathrm{NO}_{3}{ }^{-}$effluxes (negative for AU2) were lower than the depth-integrated $\mathrm{NH}_{4}{ }^{+}$production $\left(\mathrm{N}_{\text {min }}\right)$ in jars at AU1-3, while AU4 exhibited almost 3 times higher efflux than depth integrated rates. 
Table 5. On-deck rates of area-specific $\mathrm{O}_{2}$, dissolved inorganic carbon (DIC), $\mathrm{NH}_{4}{ }^{+}$and $\mathrm{NO}_{3}{ }^{-}$fluxes across the sediment-water interface at AU1-4. DOU and TOU indicate diffusive and total $\mathrm{O}_{2}$ uptake, respectively. Values are given as the average $\pm \mathrm{SD}(\mathrm{n}=4)$, except for DOU where values are average \pm range $(\mathrm{n}=2)$ for duplicate cores. Positive values indicate release from the sediment. All units are $\mathrm{mmol} \mathrm{m}^{-2} \mathrm{~d}^{-1}$

\begin{tabular}{|ccccrr|}
\hline & \multicolumn{1}{c}{ DOU } & \multicolumn{1}{c}{ TOU } & DIC & \multicolumn{1}{c|}{$\mathrm{NH}_{4}{ }^{+}$} & \multicolumn{1}{c|}{$\mathrm{NO}_{3}{ }^{-}$} \\
\hline AU1 & $-2.06 \pm 0.21$ & $-3.32 \pm 0.24$ & $5.34 \pm 1.34$ & $-0.07 \pm 0.04$ & $0.20 \pm 0.05$ \\
AU2 & $-2.10 \pm 0.04$ & $-4.49 \pm 1.11$ & $6.23 \pm 0.53$ & $-0.11 \pm 0.01$ & $-0.09 \pm 0.03$ \\
AU3 & $-9.37 \pm 5.61$ & $-15.87 \pm 1.07$ & $30.87 \pm 2.67$ & $2.05 \pm 0.31$ & $0.01 \pm 0.01$ \\
AU4 & $\sim 0$ & $-39.27 \pm 2.82$ & $55.34 \pm 6.25$ & $3.15 \pm 0.38$ & $-0.58 \pm 0.10$ \\
\hline
\end{tabular}

\section{Vertical solute profiles and non-local exchange}

$\mathrm{O}_{2}$ profiles at AU1-3 decreased steeply in a parabolic fashion with depth in the sediment (Fig. 6). The depth penetrations of $15-18 \mathrm{~mm}$ at $\mathrm{AU} 1, \sim 8 \mathrm{~mm}$ at AU2 and $\sim 4 \mathrm{~mm}$ at AU3 were inversely related to sediment reactivity. The profiles were smoother and more regular at AU1 and AU2 than at AU3 due to the near-surface activity of Amphiura filiformis at the latter station. The diffusive $\mathrm{O}_{2}$ uptake (DOU) at AU1-3 corresponded to 62,47 and $59 \%$, respectively, of the TOU at these stations.

Porewater profiles of DIC, $\mathrm{SO}_{4}{ }^{2-}$ and $\mathrm{NH}_{4}{ }^{+}$(Fig. 7) reflected the balance between reactions and transport. The porewater data from flux cores and Rumohr cores agreed well and fitted excellently to Eqs. (7) \& (8), indicating that the on-board handling of flux cores had only limited impact on porewater solutes. The lack of any fauna and bioirrigation at AU4 was clearly evident from the perfect fit to all solutes using molecular diffusion as the only transport process. Curve fitting of the data from AU1-3, however, required the consideration of bioirrigation in the form

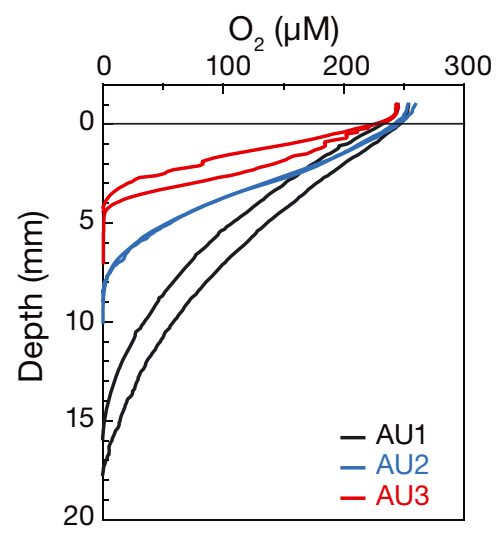

Fig. 6. Microprofiles of $\mathrm{O}_{2}$ measured on deck in freshly retrieved cores from AU1-3. Individual profiles represent the average of 2-4 replicates from each core. Two cores were profiled at each station of non-local exchange. AU2 and AU3 had almost identical surface intercepts of non-local exchange, with $\alpha_{0}$ of 0.24 to $0.34 \mathrm{~d}^{-1}$ and 0.22 to $0.38 \mathrm{~d}^{-1}$, respectively (Fig. 7); the lowest values for both stations were obtained for DIC and highest for $\mathrm{NH}_{4}{ }^{+}$. The depth attenuation $(b)$ of bioirrigation was twice as fast at AU2 than at AU3, resulting in negligible non-local exchange below $\sim 15 \mathrm{~cm}$ at the former and below $\sim 30 \mathrm{~cm}$ depth at the latter station. The surface intercept of nonlocal exchange at AU1 attained a level that was only $\sim 15 \%$ of those at the other 2 bioturbated stations for all solutes and with attenuation similar to that at AU3. Accordingly, non-local exchange at AU1 was negligible below $\sim 10 \mathrm{~cm}$ depth.

Bioirrigation estimates obtained from the on-deck $\mathrm{Br}^{-}$incubations differed strongly from those described above by diagenetic modeling (Figs. $7 \& 8$ ). Although the bioirrigation depth limits by the 2 approaches were similar for AU1 and AU2, the surficial non-local exchange coefficients $\left(\alpha_{0}\right)$ obtained by the $\mathrm{Br}^{-}$approach were only $1 / 4$ of those obtained from the diagenetic model. The opposite was evident for AU3 with 3-4 times higher $\alpha$ from the $\mathrm{Br}^{-}$approach in the upper $5 \mathrm{~cm}$ and virtually 0 below $5 \mathrm{~cm}$, while the diagenetic approach revealed significant bioirrigation down to almost $30 \mathrm{~cm}$ depth. Nevertheless, depth attenuation $(b)$ of bioirrigation was consistently 20-30 times slower in the bioturbated zone when using $\mathrm{Br}^{-}$compared with diagenetic modeling.

\section{DISCUSSION}

\section{Controls of fluxes and reaction rates}

The 4 Skagerrak-Kattegat-Belt Sea stations examined in this study evidently represent a wide range of environmental conditions and are as such ideal for the comparison of factors controlling solute fluxes and reaction rates. The reactivity of organic matter is clearly impacted by water depth and distance from land, with up to 1 order of magnitude higher fluxes and reaction rates at shallow (AU3 and AU4) than at deep stations (AU1 and AU2). This pattern is obviously related to differences in the amount, origin (Hernes \& Benner 2006) and age (Kaiser \& Benner 2009) of deposited organic matter. Thus, more reactive fractions of the organic debris disappear in transit when deposited at $>200 \mathrm{~m}$ compared with 

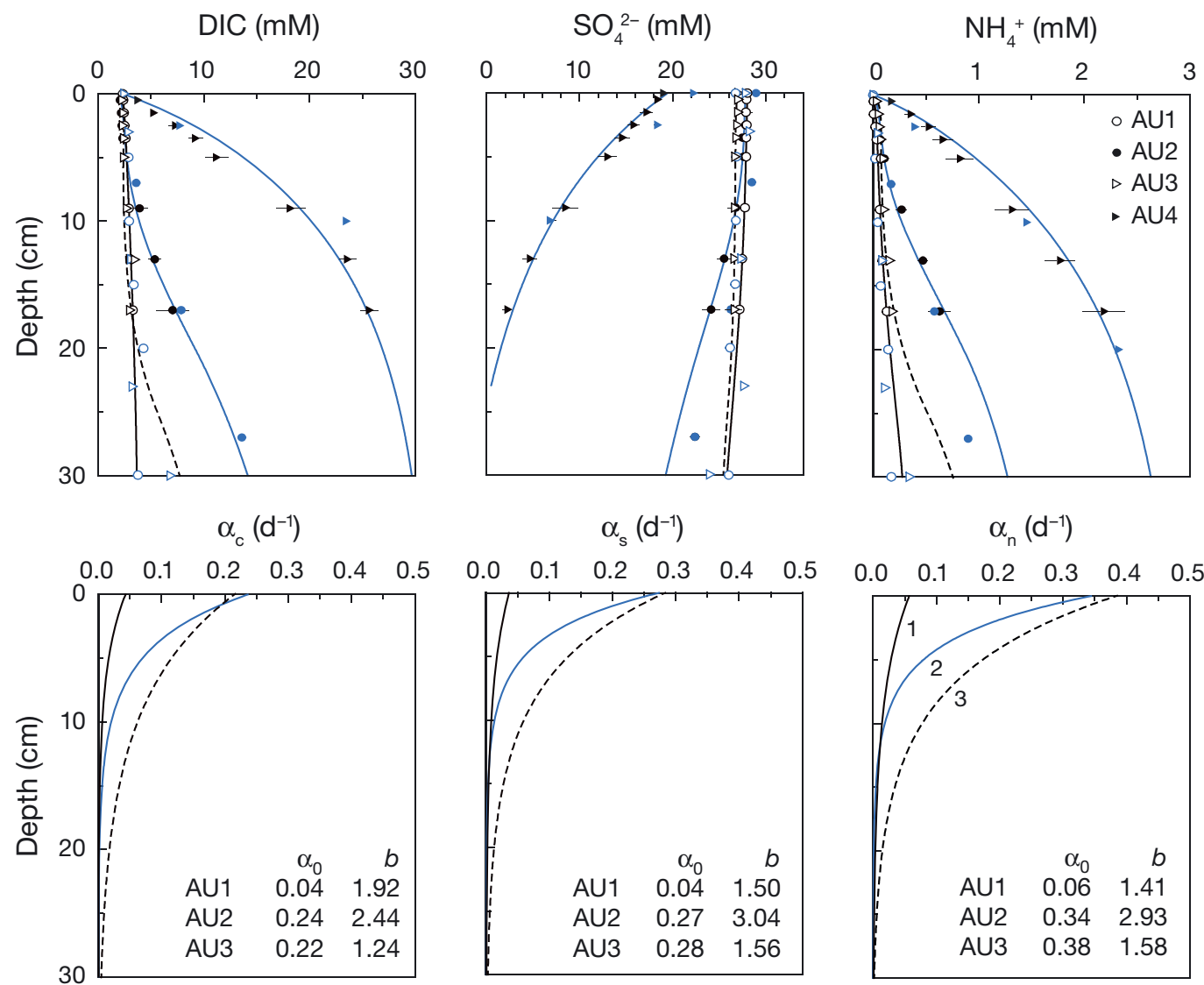

Fig. 7. Upper panels: porewater profiles of dissolved inorganic carbon (DIC), $\mathrm{SO}_{4}{ }^{2-}$, and $\mathrm{NH}_{4}{ }^{+}$at the 4 examined stations. Black symbols indicate values obtained from flux cores and blue symbols are parallel values from Rumohr cores. Curves represent the best fit according to Eqs. (7) \& (8) using the constants given in Table 4. Lower panels: depth profiles of non-local exchange coefficients required to obtain the curve fits for AU1-3 shown in the upper panel. The coefficients at the zero-depth intercept and corresponding depth-attenuation coefficients are listed

40-50 m water depth. According to McDonnell et al. (2015), the reactivity of organic particles decreases by $75 \%$ due to decay while sinking $350 \mathrm{~m}$ in the water column, which is in the same order of magnitude as the presently observed depth attenuation of benthic metabolism (Table 5). The unexpected excess organic matter in the sediment at the deep AU1 and AU2 compared with the shallow AU3 may originate from horizontal transport of poorly reactive organic matter (Dauwe et al. 1998, Ståhl et al. 2004). Accordingly, it has been proposed that the deep Skagerrak is a deposition area for fine particles transported from coastal areas to the south via the Jutland Current (Van Weering et al. 1987, Ståhl et al. 2004, Gyllencreutz \& Kissel 2006).

The stable and almost air-saturated oxic bottom water at the non-stratified Skagerrak (AU1 and AU2) and Kattegat (AU3) locations allow an innate balance between aerobic and anaerobic processes, partly driven by an abundant fauna, that maintains sediment biogeochemistry at near steady-state. AU4 in the Little Belt, on the other hand, is obviously unstable with transient state fluxes as it suffers from frequent bottom water $\mathrm{O}_{2}$ deficiency (HELCOM 2003, Conley et al. 2009), due to high benthic $\mathrm{O}_{2}$ demand combined with more or less permanent water column stratification (Diaz \& Rosenberg 2008, Lehmann et al. 2014).

The double-exponential decay profiles of $\mathrm{C}_{\mathrm{ox}}, \mathrm{SR}$ and $\mathrm{N}_{\min }$ recorded for all stations in the present study (Fig. 4) are comparable with those obtained previously in the Kattegat-Skagerrak area (Canfield et al. 1993a, Rysgaard et al. 2001, Jensen et al. 2003), but the $0-20 \mathrm{~cm}$ depth-integrated rates of, particularly, $\mathrm{C}_{\text {ox }}$ (Table 4 ) are generally lower than the corresponding DIC fluxes (Table 5). The discrepancy is partly a consequence of excluding the $\mathrm{O}_{2}$-containing surface layer and benthic fauna by isolation of sediment during anoxic incubations (Hansen \& Kristensen 1998, Kristensen et al. 1999). This shortcoming is particularly important at AU1-3, since carbon oxidation may 


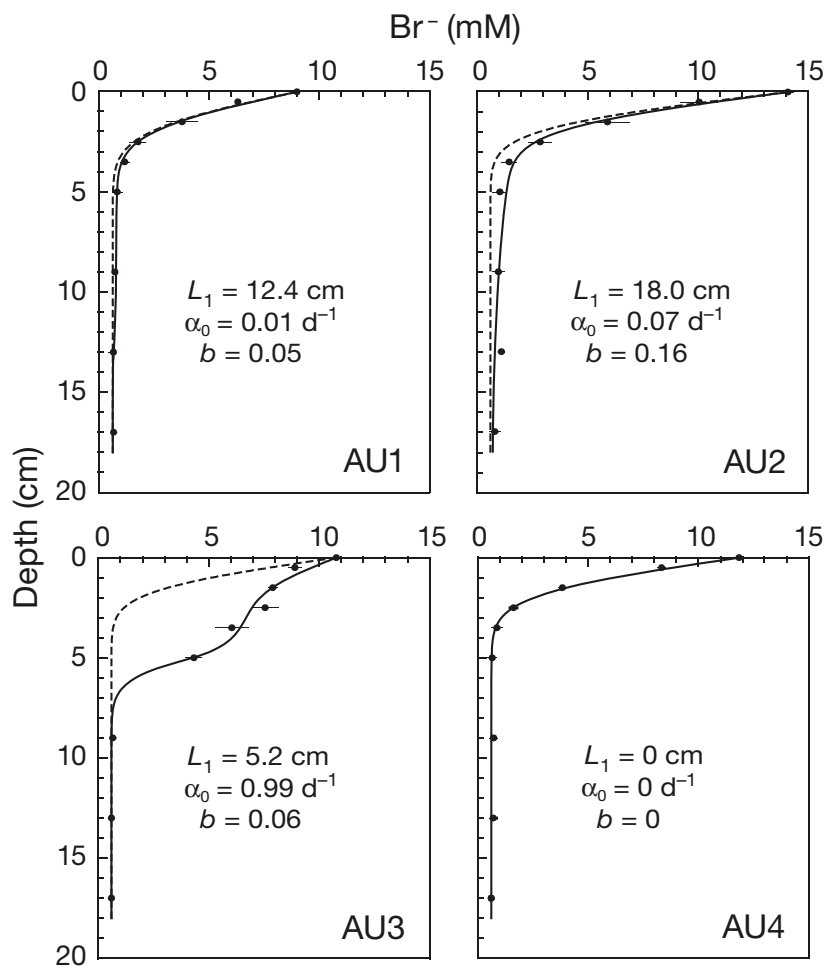

Fig. 8. Vertical $\mathrm{Br}^{-}$profiles in cores from the 4 stations incubated on deck with 8-14 $\mathrm{mM} \mathrm{Br}^{-}$in the overlying water. Symbols indicate measured points (average $\pm \mathrm{SD}, \mathrm{n}=4$ ) and full curves represent the best fit according to Eqs. (3) \& (4). The dashed curves represent estimated profiles driven by molecular diffusion alone (not applicable at AU4)

slow down by up to an order of magnitude when oxic sediment turns anoxic and benthic fauna is eliminated (Kristensen et al. 1995, Kristensen \& Holmer 2001). Furthermore, depth integration of $C_{\text {ox }}$ SR and $\mathrm{N}_{\text {min }}$ to only $20 \mathrm{~cm}$ depth may underestimate total sediment metabolism by ignoring reactions in the deep biosphere below, although the majority of carbon oxidation takes place in the upper sediment (Flury et al. 2016). On the other hand, the lower release of $\mathrm{NH}_{4}{ }^{+}$observed from flux measurements at AU1-3 (Table 5) as compared to depth-integrated $\mathrm{N}_{\min }$ (Table 4) is probably due to coupled nitrification-denitrification (Rysgaard et al. 2001) and anammox (Trimmer et al. 2013) that was absent in the anoxic incubations.

The low DOU estimated from $\mathrm{O}_{2}$ microprofiles indicates that active benthic fauna in flux cores from AU1-3 is responsible for about half of TOU, which is in accordance with Glud (2008). The direct contribution of benthic fauna respiration to TOU at AU1-3 can be estimated from the fauna biomass using a universal biomass-specific rate of 1.5 to $2.0 \mu \mathrm{mol} \mathrm{O}_{2}$ (g $\mathrm{ww})^{-1} \mathrm{~h}^{-1}$ for benthic fauna at $15^{\circ} \mathrm{C}$ (Kristensen 1989,
Vopel et al. 2003, Schröer et al. 2009). By applying a typical $Q_{10}$ of 2 for benthic fauna (Andresen \& Kristensen 2002), the direct fauna respiration at the sampled stations is estimated to account for 4 to $6 \%$ at AU1, 7 to $9 \%$ at AU2 and 41 to $55 \%$ at AU3 of TOU. The fauna contribution is low at AU1 and AU2 compared to published values of 20 to $50 \%$ (Christensen et al. 2000, Papaspyrou et al. 2010), while that at AU3 agrees well with the literature. Most of the excess TOU relative to DOU is therefore of fauna-stimulated microbial origin at AU1 and AU2, while there is limited room for a fauna-induced microbial component at AU3 as also reported for this location by Vopel et al. (2003).

\section{Benthic fauna and bioirrigation}

Fauna abundance and species richness observed in this study at the deep Skagerrak stations, AU1 and AU2 (Table 2), were similar to, but in the low range of, those found by Josefson (1985) and Rosenberg et al. (1996) for trench and slope locations in the same area. Feeding types among studies were similar with dominance of suspension-feeders near the trench (AU1) and subsurface deposit-feeders at the slope (AU2). Fauna composition at the shallow Kattegat station, AU3, was comparable to the shallow slope examined by Rosenberg (1995). Both studies found dominance of Amphiura sp. and Kurtiella bidentata, but the species richness and total abundance in the present study was in the low range of those found by Rosenberg (1995). Also in this case, the feeding types matched well between the 2 studies with complete dominance of suspension feeders. The absence of benthic fauna at AU4 was clearly caused by bottom water hypoxia (Hansen et al. 2014).

The relatively low macrofaunal biomass and the small mean individual weight in the organic-rich sediments of the deep Skagerrak are probably due to low nutritional value of the depositing organic matter (Dauwe et al. 1998). Rosenberg et al. (1996) observed a vertical discontinuity in species composition and trophic groups at about $400 \mathrm{~m}$ water depth (slope and deep basin areas), and attributed this to variations in sedimentation rate and organic matter supply. Subsurface-deposit feeders should therefore dominate below $400 \mathrm{~m}$ depth as they are generally adapted to a poor food source (Lopez \& Levinton 1987) by high sediment processing rates, selective ingestion of digestible particles and effective absorption of nutrients (Dauwe et al. 1998). Conversely, suspension feeders dominate in shallow areas where frequent 
resuspension and deposition events provide ample suspended food (Rosenberg et al. 1996). However, the dominance of the suspension feeder Spiochaetopterus typicus at the deep AU1 seems to contradict this general trend. Rosenberg et al. (1996) also noted this apparent conflict and suggested that $S$. typicus under conditions of low particle concentration may switch to surface deposit-feeding, as also reported by Fauchald \& Jumars (1979). Dauwe et al. (1998) similarly found that the vertical distribution and trophic structure of macrofauna in the North Sea-Skagerrak area reflected differences in quality of the organic matter. They found that most organisms at shallow water depth feed on freshly deposited or suspended material as interface or suspension feeders, while deeper Skagerrak sediments mainly support small-sized deeply penetrating deposit feeders.

The diagenetic transport-reaction modelling approach (Eqs. $7 \&$ 8) revealed that the 3 faunated stations (AU1-3) all were subject to substantial bioirrigation (Fig. 7). Non-local exchange of the same magnitude and depth attenuation as estimated here have been observed previously in other off-shore sediments (Martin \& Banta 1992, Forster et al. 2003, Grigg et al. 2005). The similar profile shape of nonlocal exchange coefficients $\left(\alpha_{c}, \alpha_{s}\right.$ and $\alpha_{n i}$ see Fig. 7) when estimated from fits of $\mathrm{C}_{\mathrm{ox}}, \mathrm{SR}$ and $\mathrm{N}_{\min }$ (Fig. 4) to porewater solute distributions (Fig. 7) confirms the validity of the diagenetic approach despite the above-mentioned critical assumptions regarding the depth-dependent reaction patterns. The slight solute-specific variations in the magnitude of $\alpha$, with consistently higher values for $\mathrm{NH}_{4}{ }^{+}$than for DIC and $\mathrm{SO}_{4}{ }^{2-}$, are in accordance with the diffusion-dependent predictions of Meile et al. (2005). The differences in non-local exchange observed among stations, on the other hand, were due to the functionality of the benthic fauna. The high near-surface $\alpha_{0}$ at AU3 was obviously caused by the high abundance and biomass of Amphiura filiformis (Rosenberg 1995), while the deep burrowing Callianassa tyrrhena was responsible for the relatively slow depth attenuation of $\alpha$. AU2 exhibited almost the same $\alpha_{0}$ as AU3 due to the near-surface dominance of bivalves with high capacity of ventilation. However, the lack of deeper burrowing species at AU2 caused the rapid attenuation of $\alpha$ with depth in the sediment. The overall low non-local exchange at AU1 was a consequence of low faunal activity due partly to food limitation and partly to low temperature, and dominance of small deep-burrowing and tube-forming polychaetes. These cause limited near-surface bioirrigation, but main- tain continued activity deep into the sediment as indicated by the slow depth attenuation.

Although the use of the inert tracer $\mathrm{Br}^{-}$is an elegant and easy approach to quantify bioirrigation and non-local exchange in sediments (Martin \& Banta 1992, Forster et al. 2003), it was invalid for on-deck cores in the present study. The non-local exchange coefficients obtained from transient transport modelling of $\mathrm{Br}^{-}$profiles (Eqs. 3 \& 4) after on-deck incubations were either negligible (AU1 and AU2) or very high and confined to the upper $5 \mathrm{~cm}$ (AU3) (Fig. 7). In contrast to the diagenetic approach (Eqs. $7 \&$ 8), that is based on the true in situ conditions in the sediment before sampling, the $\mathrm{Br}^{-}$method relies on bioirrigation performed by the fauna during on-deck incubations using relatively small cores. The true bioirrigation of deep tube- or burrow-dwelling species seems to be underestimated by this method due to incomplete sampling, compression and chopping of burrows and/or animals during the coring procedure (Blomqvist 1991, Eleftheriou \& Moore 2005). These damaged conditions cannot be repaired by the benthos within the short time available (hours) before start of on-deck incubations. For example, bioirrigation by Callianassa tyrrhena at AU3 was not included as this ghost shrimp inhabits burrows deeper than the coring depth. Furthermore, the benthic fauna may be disturbed by vibrations from the ship during incubations. For example, Solan et al. (2016) found that even underwater broadband sound fields can alter the activity of benthic fauna and affect their fluid and particle transport. Since the exact stress response is species-specific, ship vibrations may have slowed down the activity of the species from AU1 and AU2, while Amphiura filiformis from AU3 maintained or even increased its bioirrigation activity only in the top $5 \mathrm{~cm}$. It is therefore not recommended to use the $\mathrm{Br}^{-}$tracer approach on newly extracted sediment cores, particularly not onboard a ship. The $\mathrm{Br}^{-}$method should be restricted to laboratory incubations on pre-adapted sediment cores or homogenized sediment with a known quantity of benthic fauna added (Quintana et al. 2007). In both cases, several days must pass from core retrieval or establishment to initiation of incubation.

\section{Electron acceptor availability and the role of bioturbation}

The relative importance of aerobic microbial carbon oxidation, estimated as the difference between DIC flux and the sum of all anaerobic jar reactions, 
varies among stations in the Skagerrak-Kattegat area, ranging from $8 \%$ at AU2 to $55-60 \%$ at AU1 and AU3 of total sediment DIC flux. Although the low aerobic contribution at AU2 may substantiate an underestimate of DIC fluxes at this station, similar variability has been reported for the same area with an average of typically 50\% (Rysgaard et al. 2001). Utilization of electron acceptors driving anaerobic carbon oxidation gradually switches to more oxidized forms with increasing water depth and distance from land in accordance with the decreasing rates of $\mathrm{C}_{\mathrm{ox}}$ (Table 6). A quite consistent pattern actually emerges when all available literature data on the partitioning of anaerobic electron acceptors in sediments are compiled as a function of water depth in the Skagerrak-Kattegat-Belt Sea area (Fig. 9). Thus, SR dominates $(>50 \%$ ) in shallow water (below $40 \mathrm{~m}$ depth), decreases to $<50 \%$ when moving to deeper water, particularly below $400 \mathrm{~m}$ depth, and reaches 0 around $700 \mathrm{~m}$ depth. Conversely, FeR is virtually 0 below $40 \mathrm{~m}$ water depth and increases to 50\% below this depth and down to about $600 \mathrm{~m}$, but returns to 0 again around $700 \mathrm{~m}$ depth. $\mathrm{MnR}$, on the other hand, is close to 0 down to at least $500 \mathrm{~m}$ water depth and rapidly increases to complete dominance at $700 \mathrm{~m}$. The contribution of denitrification is generally below $10 \%$ at all depths. These depth patterns and proportions are within the range previously reported for continental margin sediments with high organic matter flux (Thamdrup 2000, Canfield et al. 2005). Particularly the dominance of $\mathrm{MnR}$ and FeR is a striking feature of deep sediments rich in Mn(IV) and Fe(III) (Aller 1990, Canfield et al. 1993a, Hyun et

Table 6. Partitioning of anaerobic electron acceptors at the 4 stations along the examined Skagerrak-Kattegat-Belt Sea depth transect in late August and early September 2014. Values are given as \% of total anaerobic carbon oxidation $\left(\mathrm{C}_{\mathrm{ox}}\right)$ according to Eq. (6) (Table 4). Denitrification (Denitr) was derived from Rysgaard et al. (2001) for AU1-3 and as the influx of $\mathrm{NO}_{3}{ }^{-}$at $\mathrm{AU} 4$, and converted to $\mathrm{C}$-units by multiplication with $4 / 5 . \mathrm{SO}_{4}$ reduction (SR) was obtained by integrating Eq. (6) below the oxic zone and to $20 \mathrm{~cm}$ depth (Table 4 ), and converted to C-units by multiplying by 2 . Fe reduction (FeR) and $\mathrm{Mn}$ reduction $(\mathrm{MnR})$ was obtained by depth-integrating the results in Fig. 6 below the oxic zone and to $20 \mathrm{~cm}$, and converted to $\mathrm{C}$-units by multiplying by $1 / 4$ and $1 / 2$, respectively

\begin{tabular}{|lcrrr|}
\hline Station & MnR & Denitr & FeR & SR \\
\hline AU1 & 33.1 & 8.4 & 40.3 & 18.3 \\
AU2 & 8.6 & 12.6 & 26.2 & 52.7 \\
AU3 & 0 & 3.0 & 28.6 & 68.4 \\
AU4 & 0 & 3.1 & 5.3 & 91.5 \\
\hline
\end{tabular}

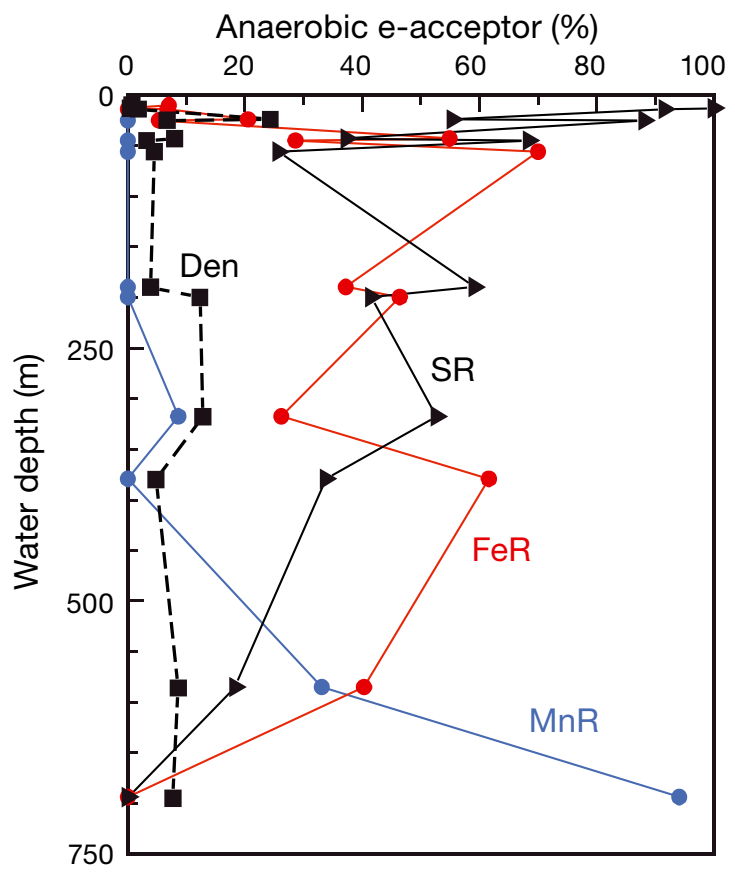

Fig. 9. Partitioning of anaerobic electron acceptors for carbon oxidation in sediments as a function of depth along the Kattegat-Skagerrak transition zone. Data stem from Canfield et al. (1993a), Rysgaard et al. (2001) and from the present study. Den: denitrification; SR: sulfate reduction; FeR: iron reduction, MnR: manganese reduction

al. 2017). While the availability of the electron acceptors $\mathrm{NO}_{3}{ }^{-}$and metal oxides (Mn(IV) and $\mathrm{Fe}(\mathrm{III})$ ) is dependent on the presence of $\mathrm{O}_{2}$ in the overlying water, SR can be supported via diffusion of $\mathrm{SO}_{4}{ }^{2-}$ into the sediment from high concentrations in the overlying seawater. Accordingly, the intense carbon oxidation in the very reactive sediments at AU4 underlying a hypoxic water column is completely dominated by SR.

While dissolved electron acceptors, $\mathrm{O}_{2}$ and $\mathrm{NO}_{3}{ }^{-}$, can readily diffuse into the sediment and are consumed within the upper few $\mathrm{cm}$, solid-phase metal oxides must be transported several cm downward by sedimentation and faunal particle reworking or be oxidized at these depths by downward translocation of $\mathrm{O}_{2}$ via faunal ventilation (bioirrigation) (Esch et al. 2013, Teal et al. 2013, Quintana et al. 2015). The annual flux of reactive $\mathrm{Fe}$ and $\mathrm{Mn}$ to the sediment at AU1-3 could, however, support less than $5 \%$ of the measured rates of metal reduction (assuming $1 \mathrm{~mm}$ sediment accumulation $\mathrm{yr}^{-1}$; Van Weering et al. 1987; L. Deng, C. C. Su, \& M. A. Lever pers. comm.). The bioturbation effects of fauna must, therefore, be the most important driver for the supply of subsurface metal oxides in the sediment (Burdige 2006, Esch et 
al. 2013). It is not known to what extent reworking, as suggested by Canfield et al. (1993a), or bioirrigation (Kristensen et al. 2012) contributes to the inventory of these important electron acceptors in the Kattegat and Skagerrak area. It has been argued that the delivery of metal oxides within the upper $10 \mathrm{~cm}$ of marine sediment is caused solely by biogenic particle mixing (Aller 1990, Canfield et al. 1993a). Hence, Canfield et al. (1993a) and Hyun et al. (2017) estimated that the measured MnR in Skagerrak and the East Sea (east of Korea) could be supported at a biodiffusion (reworking) coefficient $\left(D_{B}\right)$ of 19 and $10 \mathrm{~cm}^{2}$ $\mathrm{yr}^{-1}$, respectively. A similar calculation based on the present data reveals a need for $D_{B}$ at AU1 of $\sim 23 \mathrm{~cm}^{2}$ $\mathrm{yr}^{-1}$ that must reach down to about $10 \mathrm{~cm}$ as judged from the depth distribution of Mn(IV). However, $D_{B}$ in sediments at comparable water depths as in the Skagerrak rarely exceeds $5 \mathrm{~cm}^{2} \mathrm{y}^{-1}$ and is commonly below $1 \mathrm{~cm}^{2} \mathrm{y}^{-1}$ (Middelburg et al. 1997, Lecroart et al. 2010). In fact, $D_{B}$ at AU1 has recently been measured to $<1 \mathrm{~cm}^{2} \mathrm{y}^{-1}$ (L. Deng, C. C. Su \& M. A. Lever pers. comm.). The discrepancy becomes much worse when FeR is considered at AU2 and AU3 where the required $D_{B}$ approaches $100 \mathrm{~cm}^{2} \mathrm{y}^{-1}$ as also estimated by Canfield et al. (1993a). This greatly exceeds the measured values of $4-17 \mathrm{~cm}^{2} \mathrm{y}^{-1}$ (L. Deng, C. C. Su \& M. A. Lever pers. comm.). Accordingly, other reoxidation processes such as ventilation-driven downward translocation of $\mathrm{O}_{2}$ are required. Ventilation is several orders of magnitude faster than particle reworking (Aller 1982, Kristensen 2001), and the oxygen brought down into burrows through bioirrigation will readily oxidize $\mathrm{Fe}^{2+}$ and $\mathrm{Mn}^{2+}$ along the burrow wall and turn the sediment into a mosaic of oxidized burrow walls. At high abundances, these may even merge to form a continuous oxidized layer to $10 \mathrm{~cm}$ depth in the sediment (Norkko et al. 2011). Beam et al. (2018) similarly concluded that bioirrigation is the primary driver for rapid oxidation of $\mathrm{Fe}^{2+}$ deep in marine sediments. The metal oxides subsequently become available for microbial reduction, for example when the dynamic inhabitants abandon burrows or die. The exact partitioning between MnR and FeR then solely depends on the availability and oxidation of these metals in the sediment.

\section{Concluding remarks}

The reactivity of organic matter along the Skagerrak-Kattegat-Belt Sea transect is clearly impacted by water depth and distance from land with up to 1 order of magnitude higher fluxes and reaction rates at shallow than deep areas. The vertical distribution of reactions and partitioning of electron acceptors for carbon oxidation in sediments along this transect is dependent on the balance between the reducing capacity of the sediment due to reactions and downward transport of $\mathrm{O}_{2}$. Thus, the relatively high rates of $\mathrm{MnR}$ and $\mathrm{FeR}$ in deep water were controlled by rapid reoxidation of metals by enhanced downward translocation of $\mathrm{O}_{2}$ into the low reactive anoxic sediment through ventilation-driven bioirrigation by the infauna.

The present study also concludes that quantification of bioirrigation of newly retrieved sediment cores onboard a ship should preferably be done by diagenetic transport-reaction modelling rather than the widely used $\mathrm{Br}^{-}$incubation technique. However, it is suggested that future studies look closer into the comparison of methods to estimate bioirrigation to confirm this supposition. Furthermore, there is a strong need for research on the role of individual fauna species and functional groups for bioirrigation and reoxidation of metals in deep sediments. If successful, the obtained results can be valuable in future evaluations and mapping of key biogeochemical mechanisms and conditions in oceanic sediments.

Acknowledgements. We thank the captain, crew, and scientific team on the 'Aurora' for assistance during the cruise in 2014. The cruise was granted by the Danish Center for Marine Research under the name LOWLIFE, led by Bo Barker Jørgensen. The study received funding from an ERC Advanced Grant to Bo Barker Jørgensen (MICROENERGY, EU 7th 937 FP, grant \# 294200), and by the Danish National Research Foundation (DNRF grant \# 104). E.K. was supported by the Danish Council for Independent Research (contract \# 12-127012).

\section{LITERATURE CITED}

Aller RC (1982) The effects of macrobenthos on chemical properties of marine sediment and overlying water. In: McCall PL \& Tevesz MJS (eds) Animal-sediment relations. Plenum, New York, NY, p 53-102

Aller RC (1990) Bioturbation and manganese cycling in hemipelagic sediments. Philos Trans R Soc Lond, A 331: 51-68

Aller RC (2014) Sedimentary diagenesis, depositional environments, and benthic fluxes. In: Holland HD, Turekian KK (eds) Treatise on Geochemistry, Vol 8, 2nd edn. Elsevier, Oxford, p 293-334

Andresen M, Kristensen E (2002) The importance of bacteria and microalgae in the diet of the deposit-feeding polychaete Arenicola marina. Ophelia 56:179-196

Armstrong FAJ, Stearns CR, Strickland JDH (1967) The measurement of upwelling and subsequent biological processes by means of the Technicon Autoanalyzer® and associated equipment. Deep-Sea Res 14:381-389 
Beam JP, Scott JJ, McAllister SM, Chan CS, McManus J, Meysman FJR, Emerson D (2018) Biological rejuvenation of iron oxides in bioturbated marine sediments. ISME J 12:1389-1394

Berner RA (1980) Early diagenesis: a theoretical approach. Princeton University Press, Princeton, NJ

Blomqvist S (1991) Quantitative sampling of soft-bottom sediments: problems and solutions. Mar Ecol Prog Ser 72: 295-304

Boudreau BP (1997) Diagenetic models and their implementation. Modelling transport and reactions in aquatic sediments. Springer, Berlin

Boudreau BP (1998) Mean mixed depth of sediments: the wherefore and the why. Limnol Oceanogr 43:524-526

Bower CE, Holm-Hansen T (1980) A salicylate-hypochlorite method for determining ammonia in seawater. Can J Fish Aquat Sci 37:794-798

Burdige DJ (2006) Geochemistry of marine sediments. Princeton University Press, Princeton, NJ

Canfield DE, Jørgensen BB, Fossing H, Glud R and others (1993a) Pathways of organic carbon oxidation in three continental margin sediments. Mar Geol 113:27-40

Canfield DE, Kristensen E, Thamdrup B (2005) Aquatic geomicrobiology. Adv Mar Biol, Vol 48. Academic Press, San Diego, CA

Canfield DE, Thamdrup B, Hansen JW (1993b) The anaerobic degradation of organic matter in Danish coastal sediments: iron reduction, manganese reduction, and sulfate reduction. Geochim Cosmochim Acta 57:3867-3883

Christensen B, Vedel A, Kristensen E (2000) Carbon and nitrogen fluxes in sediment inhabited by suspensionfeeding (Nereis diversicolor) and non-suspension-feeding (Nereis virens) polychaetes. Mar Ecol Prog Ser 192: 203-217

Coleman TF, Li Y (1994) On the convergence of interiorreflective Newton methods for nonlinear minimization subject to bounds. Math Program 67:189-224

Coleman TF, Li Y (1996) An interior trust region approach for nonlinear minimization subject to bounds. SIAM J Optim 6:418-445

Conley DJ, Carstensen J, Vaquer-Sunyer R, Duarte CM (2009) Ecosystem thresholds with hypoxia. Hydrobiologia 629:21-29

Dauwe B, Herman PMJ, Heip CHR (1998) Community structure and bioturbation potential of macrofauna at four North Sea stations with contrasting food supply. Mar Ecol Prog Ser 173:67-83

* DeMaster DJ, McKee BA, Nittrouer CA, Jiangchu Q, Guodong C (1985) Rates of sediment accumulation and particle reworking based on radiochemieal measurements from continental shelf deposits in the East China Sea. Cont Shelf Res 4:143-158

Diaz RJ, Rosenberg R (2008) Spreading dead zones and consequences for marine ecosystems. Science 321:926-929

Eleftheriou A, Moore DC (2005) Macrofauna techniques. In: Eleftheriou A, McIntyre A (eds) Methods for the study of marine benthos, 3rd edn. Blackwell Science, Oxford, p 160-228

Esch MES, Shull DH, Devol AH, Moran SB (2013) Regional patterns of bioturbation and iron and manganese reduction in the sediments of the southeastern Bering Sea. Deep-Sea Res II 94:80-94

Fauchald K, Jumars PA (1979) The diet of worms: a study of polychaete feeding guilds. Oceanogr Mar Biol Ann Rev 17:193-284
Flury S, Røy H, Dale AW, Fossing H and others (2016) Controls on subsurface methane fluxes and shallow gas formation in Baltic Sea sediment (Aarhus Bay, Denmark). Geochim Cosmochim Acta 188:297-309

Forster S, Khalili A, Kitlar J (2003) Variation of nonlocal irrigation in a subtidal benthic community. J Mar Res 61: 335-357

Glud RN (2008) Oxygen dynamics of marine sediments. Mar Biol Res 4:243-289

* Grigg NJ, Boudreau BP, Webster IT, Ford PW (2005) The nonlocal model of porewater irrigation: limits to its equivalence with a cylinder diffusion model. J Mar Res 63:437-455

*Gyllencreutz R, Kissel C (2006) Lateglacial and Holocene sediment sources and transport patterns in the Skagerrak interpreted from high-resolution magnetic properties and grain size data. Quat Sci Rev 25:1247-1263

*Hall POJ, Aller RC (1992) Rapid, small-volume, flow injection analysis for $\Sigma \mathrm{CO}_{2}$, and $\mathrm{NH}_{4}{ }^{+}$in marine and freshwaters. Limnol Oceanogr 37:1113-1119

Hansen K, Kristensen E (1998) The impact of the polychaete Nereis diversicolor and enrichment with macroalgal (Chaetomorpha linum) detritus on benthic metabolism and nutrient dynamics in organic-poor and organic-rich sediment. J Exp Mar Biol Ecol 231:201-223

Hansen JW, Rytter D, Skovbjerg Balsby TJ (2015) Iltsvind i de danske farvande i august-september 2014. Rapporteringsperiode: 21. august - 17. september. Revised 23 June 2015. Nationalt Center for Miljø og Energi, Aarhus (in Danish with English summary). https://mst.dk/media/ 118293/iltsvindsrapport_august_september-2014_final.pdf

HELCOM (2003) The 2002 oxygen depletion event in the Kattegat, Belt Sea and Western Baltic. Baltic Sea Environment Proceedings 90. Helsinki Commission, Baltic Marine Environment Protection Commission, Helsinki

Heip CHR, Herman PMJ, Soetaert K (1998) Indices of diversity and evenness. Oceanis 24:61-87

*Hernes PJ, Benner R (2006) Terrigenous organic matter sources and reactivity in the North Atlantic Ocean and a comparison to the Arctic and Pacific oceans. Mar Chem 100:66-79

*Holmboe N, Kristensen E (2002) Ammonium adsorption in sediments of a tropical mangrove forest (Thailand) and a temperate Wadden Sea area (Denmark). Wetlands Ecol Manage 10:453-460

*Hyun JH, Kim SH, Mok JS, Cho H, Lee T, Vandieken V, Thamdrup B (2017) Manganese and iron reduction dominate organic carbon oxidation in surface sediments of the deep Ulleung Basin, East Sea. Biogeosciences 14:941-958

* Jensen MM, Thamdrup B, Rysgaard S, Holmer M, Fossing H (2003) Rates and regulation of microbial iron reduction in sediments of the Baltic-North Sea transition. Biogeochemistry 65:295-317

Josefson AB (1985) Distribution of diversity and functional groups of marine benthic infauna in the Skagerrak (eastern North Sea)-Can larval availability affect diversity? Sarsia 70:229-249

Kaiser K, Benner R (2009) Biochemical composition and size distribution of organic matter at the Pacific and Atlantic time-series stations. Mar Chem 113:63-77

Kierzenka J, Shampine LF (2001) A BVP solver based on residual control and the MATLAB PSE. ACM Trans Math Softw 27:299-316

K Kostka JE, Gribsholt B, Petrie E, Dalton D, Skelton H, Kristensen $\mathrm{E}$ (2002) The rates and pathways of carbon oxida- 
tion in bioturbated saltmarsh sediments. Limnol Oceanogr 47:230-240

Kristensen E (1989) Oxygen and carbon dioxide exchange in the polychaete Nereis virens: Influence of ventilation activity and starvation. Mar Biol 101:381-388

Kristensen E (2001) Impact of polychaetes (Nereis spp. and Arenicola marina) on carbon biogeochemistry in coastal marine sediment. Geochem Trans 2:92-104

Kristensen E, Ahmed SI, Devol AH (1995) Aerobic and anaerobic decomposition of organic matter in marine sediment: Which is fastest? Limnol Oceanogr 40:1430-1437

Kristensen E, Devol AH, Hartnett HE (1999) Organic matter diagenesis in sediments on the continental shelf and slope of the eastern tropical and temperate North Pacific. Cont Shelf Res 19:1331-1351

Kristensen E, Hansen K (1999) Transport of carbon dioxide and ammonium in bioturbated (Nereis diversicolor) coastal, marine sediments. Biogeochemistry 45:147-168

Kristensen E, Holmer M (2001) Decomposition of plant materials in marine sediment exposed to different electron acceptors $\left(\mathrm{O}_{2}, \mathrm{NO}_{3}{ }^{-}\right.$and $\left.\mathrm{SO}_{4}{ }^{2-}\right)$, with emphasis on substrate origin, degradation kinetics and the role of bioturbation. Geochim Cosmochim Acta 65:419-434

Kristensen E, Penha-Lopes G, Delefosse M, Valdemarsen T, Quintana CO, Banta GT (2012) What is bioturbation? The need for a precise definition for fauna in aquatic sciences. Mar Ecol Prog Ser 446:285-302

Kristiansen KD, Kristensen E, Jensen EMH (2002) The influence of water column hypoxia on the behaviour of manganese and iron in sandy coastal marine sediment. Estuar Coast Shelf Sci 55:645-654

Krom MD, Berner RA (1980) Adsorption of phosphate in anoxic marine sediments. Limnol Oceanogr 25:797-806

* Lecroart P, Maire O, Schmidt S, Grémare A, Anschutz P, Meysman FJR (2010) Bioturbation, short-lived radioisotopes, and the tracer-dependence of biodiffusion coefficients. Geochim Cosmochim Acta 74:6049-6063

* Lehmann A, Hinrichsen HH, Getzlaff K, Myrberg K (2014) Quantifying the heterogeneity of hypoxic and anoxic areas in the Baltic Sea by a simplified coupled hydrodynamic-oxygen consumption model approach. J Mar Syst 134:20-28

Li YH, Gregory S (1974) Diffusion of ions in seawater and in deep-sea sediments. Geochim Cosmochim Acta 38: 703-714

Lopez GR, Levinton JS (1987) Ecology of deposit-feeding animals in marine sediments. Q Rev Biol 62:235-260

* Lovley DR, Phillips EJP (1987) Rapid assay for microbially reducible ferric iron in aquatic sediments. Appl Environ Microbiol 53:1536-1540

Martin WR, Banta GT (1992) The measurement of sediment irrigation rates: a comparison of the $\mathrm{Br}^{-}$tracer and ${ }^{222} \mathrm{Rn} /{ }^{226} \mathrm{Ra}$ disequilibrium techniques. J Mar Res 50: 125-154

* McDonnell AMP, Boyd PW, Buesseler KO (2015) Effects of sinking velocities and microbial respiration rates on the attenuation of particulate carbon fluxes through the mesopelagic zone. Global Biogeochem Cycles 29: 175-193

* Meile C, Berg P, van Cappellen P, Tuncay K (2005) Solutespecific pore water irrigation: Implications for chemical cycling in early diagenesis. J Mar Res 63:601-621

* Meile C, Koretsky CM, van Cappellen P (2001) Quantifying bioirrigation in aquatic sediments: an inverse modeling approach. Limnol Oceanogr 46:164-177
Meysman FJR, Galaktionov OS, Gribsholt B, Middelburg JJ (2006) Bioirrigation in permeable sediments: Advective pore-water transport induced by burrow ventilation. Limnol Oceanogr 51:142-156

Middelburg JJ, Soetaert K, Herman PMJ (1997) Empirical relationships for use in global diagenetic models. DeepSea Res I 44:327-344

Norkko J, Reed DC, Timmermann K, Norkko A and others (2011) A welcome can of worms? Hypoxia mitigation by an invasive species. Glob Change Biol 18:422-434

Papaspyrou S, Thessalou-Legaki M, Kristensen E (2010) The influence of infaunal (Nereis diversicolor) abundance on degradation of organic matter in sandy sediments. J Exp Mar Biol Ecol 393:148-157

*Quintana CO, Tang M, Kristensen E (2007) Simultaneous study of particle reworking, irrigation transport and reaction rates in sediment bioturbated by the polychaetes Heteromastus and Marenzelleria. J Exp Mar Biol Ecol 352:392-406

* Quintana CO, Shimabukuro M, Pereira CO, Alves BGR and others (2015) Carbon mineralization pathways and bioturbation in coastal Brazilian sediments. Sci Rep 5:16122

* Revsbech NP (1989) An oxygen microsensor with a guard cathode. Limnol Oceanogr 34:474-478

* Rosenberg R (1995) Benthic marine fauna structured by hydrodynamic processes and food availability. Neth J Sea Res 34:303-317

Rosenberg R, Hellman B, Lundberg A (1996) Benthic macrofaunal community structure in the Norwegian Trench, deep Skagerrak. J Sea Res 35:181-188

* Rysgaard S, Fossing H, Jensen MM (2001) Organic matter degradation through oxygen respiration, denitrification, and manganese, iron, and sulfate reduction in marine sediments (the Kattegat and the Skagerrak). Ophelia 55:77-91

* Schimmelmann A, Lange CB, Schieber J, Francus P, Ojala AEK, Zolitschka B (2016) Varves in marine sediments: A review. Earth Sci Rev 159:215-246

* Schröer M, Wittmann AC, Grüner N, Steeger HU, Bock C, Paul R, Pörtner HO (2009) Oxygen limited thermal tolerance and performance in the lugworm Arenicola marina: a latitudinal comparison. J Exp Mar Biol Ecol 372:22-30

* Shampine LF, Reichelt MW (1997) The MATLAB ODE suite. SIAM J Sci Comput 18:1-22

* Shampine LF, Reichelt MW, Kierzenka JA (1999) Solving index-1 DAEs in MATLAB and Simulink. SIAM Rev 41: $538-552$

Shull DH, Benoit JM, Wojcik C, Senning JR (2009) Infaunal burrow ventilation and pore-water transport in muddy sediments. Estuar Coast Shelf Sci 83:277-286

* Skeel RD, Berzins M (1990) A method for the spatial discretization of parabolic equations in one space variable. SIAM J Sci Statist Comput 11:1-32

* Solan M, Hauton C, Godbold JA, Wood CL, Leighton TG, White P (2016) Anthropogenic sources of underwater sound can modify how sediment-dwelling invertebrates mediate ecosystem properties. Sci Rep 6:20540

* Ståhl H, Tengberg A, Brunnegård J, Bjørnbom E and others (2004) Factors influencing organic carbon recycling and burial in Skagerrak sediments. J Mar Res 62:867-907

* Teal LR, Bulling MT, Parker ER, Solan M (2008) Global patterns of bioturbation intensity and mixed depth of marine soft sediments. Aquat Biol 2:207-218

Teal LR, Parker ER, Solan M (2013) Coupling bioturbation activity to metal (Fe and $\mathrm{Mn}$ ) profiles in situ. Biogeosciences 10:2365-2378 
Thamdrup B (2000) Bacterial manganese and iron reduction in aquatic sediments. In: Schink B (ed) Adv Microb Ecol, Vol 16. Kluwer Academic/Plenum Publishers, New York, NY, p 41-84

Thamdrup B, Glud RN, Hansen JW (1994) Manganese oxidation and in situ manganese fluxes from a coastal sediment. Geochim Cosmochim Acta 58:2563-2570

Trimmer M, Engström P, Thamdrup B (2013) Stark contrast in denitrification and anammox across the deep Norwegian Trench in the Skagerrak. Appl Environ Microbiol 79:7381-7389

van de Velde S, Meysman FJR (2016) The influence of bioturbation on iron and sulphurcycling in marine sediments: A model analysis. Aquat Geochem 22:469-504

Vandieken V, Nickel M, Jørgensen BB (2006) Carbon mineralization in Arctic sediments northeast of Svalbard:

Editorial responsibility: Robinson Fulweiler,

Boston, Massachusetts, USA
$\mathrm{Mn}(\mathrm{IV})$ and $\mathrm{Fe}(\mathrm{III})$ reduction as principal anaerobic respiratory pathways. Mar Ecol Prog Ser 322:15-27

Van Weering TCE, Berger GW, Kalf J (1987) Recent sediment accumulation in the Skagerrak, northeastern North Sea. Neth J Sea Res 21:177-189

*Vopel K, Thistle D, Rosenberg R (2003) Effect of the brittle star Amphiura filiformis (Amphiuridae, Echinodermata) on oxygen flux into the sediment. Limnol Oceanogr 48: 2034-2045

*Weissberger EJ, Jumars PA, Mayer LM, Schick LL (2008) Structure of a northwest Atlantic Shelf macrofaunal assemblage with respect to seasonal variation in sediment nutritional quality. J Sea Res 60:164-175

*Westrich JT, Berner RA (1984) The role of sedimentary organic matter in bacterial sulfate reduction: the $G$ model tested. Limnol Oceanogr 29:236-249

Submitted: March 5, 2018; Accepted: August 22, 2018

Proofs received from author(s): September 24, 2018 